\title{
A systematic GIS-based analysis of settlement developments in the landscape of Venusia in the Hellenistic-Roman period
}

\author{
Anita Casarotto $^{1}$ (ID ) Jeremia Pelgrom ${ }^{2} \cdot$ Tesse D. Stek $^{1}$
}

Received: 23 March 2017 / Accepted: 30 October 2017 /Published online: 25 November 2017

(C) The Author(s) 2017. This article is an open access publication

\begin{abstract}
This paper investigates the settlement developments of the landscape around the ancient town of Venusia in southern Italy using legacy field survey data. A Latin colony was established here in $291 \mathrm{BC}$ and also other subsequent Roman colonization movements are known from the literary sources. As in many other Roman colonial landscapes, trends in the settlement data of Venusia have previously been linked to the impact of Roman colonization, which is usually understood as a drastic transformation of the pre-Roman settlement landscape and land use. Rather than using theories on Roman colonial strategies for explaining possible settlement patterns (deductive approach), this paper presents an alternative, descriptive, bottom-up approach, and GIS-based inductive location preference analysis to investigate how the settlement landscape evolved in the Hellenistic and Roman periods (particularly in the fourth-first century BC). Following closely the settlement choices from the pre-Roman conquest period onwards and assessing patterns in continuity and change in the settlement record, we demonstrate that pre-Roman rural
\end{abstract}

Electronic supplementary material The online version of this article (https://doi.org/10.1007/s12520-017-0561-y) contains supplementary material, which is available to authorized users.

Anita Casarotto

a.casarotto@arch.leidenuniv.nl

Jeremia Pelgrom

j.pelgrom@knir.it

Tesse D. Stek

t.d.stek@arch.leidenuniv.nl

1 Faculty of Archaeology, Leiden University, Van Steenis Building, Einsteinweg 2, 2333 CC Leiden, the Netherlands

2 Royal Netherlands Institute in Rome (KNIR), via Omero 10/12, 00197 Rome, Italy settlement and land use strategies were not eradicated but instead strongly determined the location preferences for later settlements in the "colonial" periods. If these settlement trends can be related at all to the colonization waves mentioned in the ancient literary sources, the conclusion should be that Roman colonization did not lead to radical landscape and land use transformations, as has traditionally been suggested. Instead, an organic and complementary rural infill over time is documented, in which cultural factors instead of land use potential played a key role.

Keywords Roman colonization · Settlement strategy · Inductive analysis $\cdot$ Location preferences $\cdot$ Cultural factors . Marginal zone $\cdot$ Integrated-clustered rural infill

\section{Introduction}

The formation of early Roman colonial landscapes has often been reconstructed using literary evidence on Roman colonization strategies, which for the most part was written after the Civil Wars (first century BC). Several recent studies have stressed the high risk of anachronism underlying such an approach and have highlighted the dangers of adopting synchronic text-based approaches to understand previous midRepublican colonization practices (e.g., Crawford 1995; Torelli 1999; Bispham 2006; Patterson 2006; Pelgrom and Stek 2014). In this paper, a different approach to understanding colonial settlement strategies is offered, using a GIS-based quantitative and qualitative analysis of settlement behavior and location preferences in the colonial landscape of Venusia. This paper complements and further expands the research strategy outlined in a set of previous articles, which have, instead, focused on settlement pattern analysis and deductive reasoning (Casarotto et al. 2016) and survey 
methodological issues (Casarotto et al. 2017). As such, it offers a useful approach to use legacy, site-based datasets for territorial investigations. The aim here is to move from point observations to area-based interpretations of the ancient settlement processes underpinning site configurations, to get a firm grip on the evolution and morphogenesis of the landscape as a whole (see also discussion in De Guio 1985).

The territory of Venusia presents a particularly rich case-study in which to investigate settlement developments in relation to Roman colonization. Thanks to the work by M.L. Marchi and G. Sabbatini (Marchi and Sabbatini 1996; Sabbatini 2001; Marchi 2010), it is one of the best-studied Roman colonial territories in Italy. Additionally, it has, according to the literary sources, witnessed a whole series of colonial settlements. At least in theory, this offers the opportunity to assess possible changes in settlement strategies in relation to Roman colonialism over time. In the third century $\mathrm{BC}$, as part of its expansionistic enterprise taking place across the entire Italian peninsula, Rome sent out the first wave of colonists to settle in this territory. Subsequently, other groups of colonists are reported to have been sent there, in $200 \mathrm{BC}$ (allegedly to repopulate the region after the Second Punic War), at the end of the second century $\mathrm{BC}$ (as a response to the Gracchan land reforms), and later on in the Triumviral period (perhaps Augustus's veterans of the battle of Philippi) (for discussion of the sources see Marchi and Sabbatini 1996: 19-21; Marchi 2000: 229; Marchi 2010: 40; Marchi 2014: 182-183). Of course, just as it is impossible to equate certain pots with certain people (see discussion in Shennan 1994; Bintliff and Sbonias 2000; Dores Cruz 2011), it is impossible to equate surface sites directly with an influx of Roman colonists. It is possible, however, to assess how the settlement organization as a whole, as reflected in site distributions, evolved over the time period for which colonization is documented to have taken place. Subsequently, we can explore how the documented trends can be related to historically known colonization events, although it will remain hard, with the current methods and data at our disposal, to tease such trends out from wider Italic or indeed Mediterranean phenomena in the present context (in general Terrenato 2007; Attema et al. 2010; Stek 2013: esp. 340-343; for Venusia see Stek 2012: 244; cf. landscapesofearlyromancolonization.com for a research design that takes this into account).

The source dataset for our analysis here consists of diachronic and hierarchical point distributions of archaeological sites recorded during field surveys (Marchi and Sabbatini 1996; Sabbatini 2001; Marchi 2010). The potential and limits of this dataset have already been discussed elsewhere (e.g., specifically on Venusia: Stek 2012; Casarotto et al. 2016; in general e.g., Fentress 2000 with further references).

In this paper, we analyze the long-term development of the settlement landscape in two ways. First, we compared the preRoman settlement organization, with nucleated settlements and their possible catchment areas, to later developments in the settlement organization up to the Imperial period. In this way, we established that the pre-colonial settlement pattern played an important role in influencing the location of new settlements. Second, we tested this finding with an inductive location preference analysis, which allowed a more quantitative assessment of the correlations between settlement and cultural or natural factors. As we will see, we found a stronger effect of cultural than of natural factors on colonial period settlement locations.

\section{Data}

The following analysis capitalizes on the legacy survey data collected during a regional, site-oriented field survey project, namely the Forma Italiae-Ager Venusinus project (Marchi and Sabbatini 1996; Sabbatini 2001; Marchi 2010). In addition to the identification of sites at the surface (threshold sets at 5 sherds per square meter) on a territory of ca. $700 \mathrm{~km}^{2}$, careful attention was paid during survey to those factors that could have affected the discovery of sites, such as ground visibility conditions (Marchi and Sabbatini 1996: 107; Azzena and Tascio 1996: 292-294; Sabbatini 2001: 59). The implications of possible distorting factors on site recovery are discussed in detail elsewhere; in this context, it suffices to state that there is little reason to assume that surface visibility conditions strongly biased the site patterns detected during the Forma Italiae survey.

In contrast to previous analyses of these legacy survey data, in this paper, the data are not used to confirm or discard existing theories about Roman settlement strategies (i.e., a deductive approach, see Casarotto et al. 2016, for another Roman context see Goodchild 2007: 180-328; 2013). Instead, the data are subjected to statistical analysis to see whether any trend in site patterning with respect to the natural and cultural environment emerges (an inductive approach) (see Kamermans and Wansleeben 1999; Van Leusen and Kamermans 2005 with further references; for another Roman context see Goodchild 2007: 121-176). Only as a last step, we will consider how the detected trends compare to existing theories on Roman colonization.

In this analysis, site samples are organized both diachronically (i.e., per period) and hierarchically (i.e., per size category) (Table 1). Previous attempts to classify survey site types based on function (e.g., farm, activity area, villa, etc., see Marchi and Sabbatini 1996; Sabbatini 2001; Marchi 2010) are not considered in this paper because of the debated nature of such definitions (see the discussions in Barker and Lloyd 1991; Barker and Mattingly 1999; Bintliff and Sbonias 1999; Francovich et al. 2000; Rathbone 2008; Witcher 2008; Launaro 2011: 85-88; Fracchia 2013: 185-190; esp. for the Ager Venusinus data see Stek 2012). By disregarding typological classifications, interpretative biases and variations in definition are limited (see van Leusen 2002, ch. 4) and site distributions can be compared on the basis of common formal attributes, such as size and period. 
Table 1 Legacy survey data organized per period and per size. Archaeological sites were identified by teams of three to five surveyors spaced at 5- to 10-m intervals, on a territory of ca. $700 \mathrm{~km}^{2}$, using a minimum threshold of 5 sherds per square meter (see Marchi and Sabbatini 1996; Sabbatini 2001; Marchi 2010)

\begin{tabular}{|c|c|c|c|c|c|c|}
\hline & \multicolumn{6}{|c|}{ Settlement size (sq m) } \\
\hline & $0-100$ & $101-400$ & $401-800$ & $801-2000$ & $>2000$ & Tot. \\
\hline Pre-Roman settlements (fifth-fourth century BC) & 100 & 88 & 34 & 45 & 22 & 289 \\
\hline Early colonial period settlements (third century BC) & 18 & 34 & 9 & 18 & 10 & 89 \\
\hline Inherited settlements & 7 & 13 & 6 & 6 & 7 & 39 \\
\hline New Early colonial period settlements & 11 & 21 & 3 & 12 & 3 & 50 \\
\hline Republican settlements (third-first century BC) & 168 & 218 & 74 & 109 & 37 & 606 \\
\hline Inherited settlements & 20 & 21 & 12 & 13 & 10 & 76 \\
\hline New Republican settlements & 148 & 197 & 62 & 96 & 27 & 530 \\
\hline Late-Republican-Triumviral settlements (first century BC-33 AD) & 78 & 138 & 64 & 93 & 37 & 410 \\
\hline Inherited settlements & 22 & 62 & 25 & 51 & 27 & 187 \\
\hline New Late Republican-Triumviral settlements & 56 & 76 & 39 & 42 & 10 & 223 \\
\hline Imperial settlements (first-fourth/fifth century AD) & 144 & 194 & 78 & 125 & 53 & 594 \\
\hline Inherited settlements ${ }^{\mathrm{a}}$ & 9 & 8 & 5 & 13 & 4 & 39 \\
\hline Inherited settlements & 34 & 78 & 32 & 72 & 36 & 252 \\
\hline New Imperial settlements & 101 & 108 & 41 & 40 & 13 & 303 \\
\hline Uncertain Pre-Roman-Imperial settlements & 19 & 12 & 4 & 7 & 6 & 48 \\
\hline
\end{tabular}

${ }^{\text {a }}$ These sites are not occupied in the Late Republican-Triumviral period but have a Republican phase of occupation

Another aspect must be noted at this point. We decided to consider the third century BC settlement sample in the analyses because we are interested in assessing the settlement trends after the first colonization movement of 291 BC. The selection of surely datable early colonial sites is mainly based on the presence of diagnostic and datable third century BC black gloss pottery. Because such precisely datable finds are often not present in small sites, is it likely that the number of early colonial period sites included in this sample is an underestimation (see discussion in Casarotto et al. 2016: 569-570). It is therefore probable that several third century BC sites are now included in the broader Republican sample (see also Marchi and Sabbatini 1996: 111, note 129; Marchi 2010: 258). For this paper, however, we decided to ascertain whether any pattern emerges from the early colonial sample bearing in mind its small size and the likely missing evidence.

\section{Exploring the pre-Roman and Roman landscapes}

In this first section, we explore how sites in the early colonial period were placed with respect to the previous settlement organization. First, we describe this pre-Roman settlement organization in qualitative terms by comparing the site patterning to several landscape properties.
Subsequently, we adopt GIS-based visualization techniques to enhance the identified relationships. We use computer-based simulation here only as a support for highlighting relationships already noted through the descriptive analysis, not as a means to find them.

The territory investigated in this paper corresponds to the north-eastern part of the modern Basilicata region, at the border with Apulia. This area is located between the southern Apennine mountains and the Apulian plain. In ancient times, it was a zone of transition between different physical, but also cultural, units (i.e., ecotone, see Odum 1959: 278-280). As a matter of fact, this southern Italian territory corresponded to a "frontier" zone between the territories of Daunia (Northern Apulia), Lucania (Basilicata and southern Campania), and Samnium (central-southern Apennines), inhabited in preRoman times by vibrant native polities (Salmon 1967; Bottini 1980, 1982, 2016 with further references; Volpe 1990; Tagliamonte 1996; Isayev 2007; Osanna 2010; Marchi 2009, 2016 with further references). As pointed out by De Cazanove (2005), the position of this area in-between different cultural regions may well explain the choice to establish the Latin colony here, since Latin colonies were often located at frontier areas between different Italic polities (see also Torelli 1992; Marchi and Sabbatini 1996: 17-21; Marchi and Salvatore 1997: 5; Musti 2009; Marchi 2010: 29-31, 35-39). 


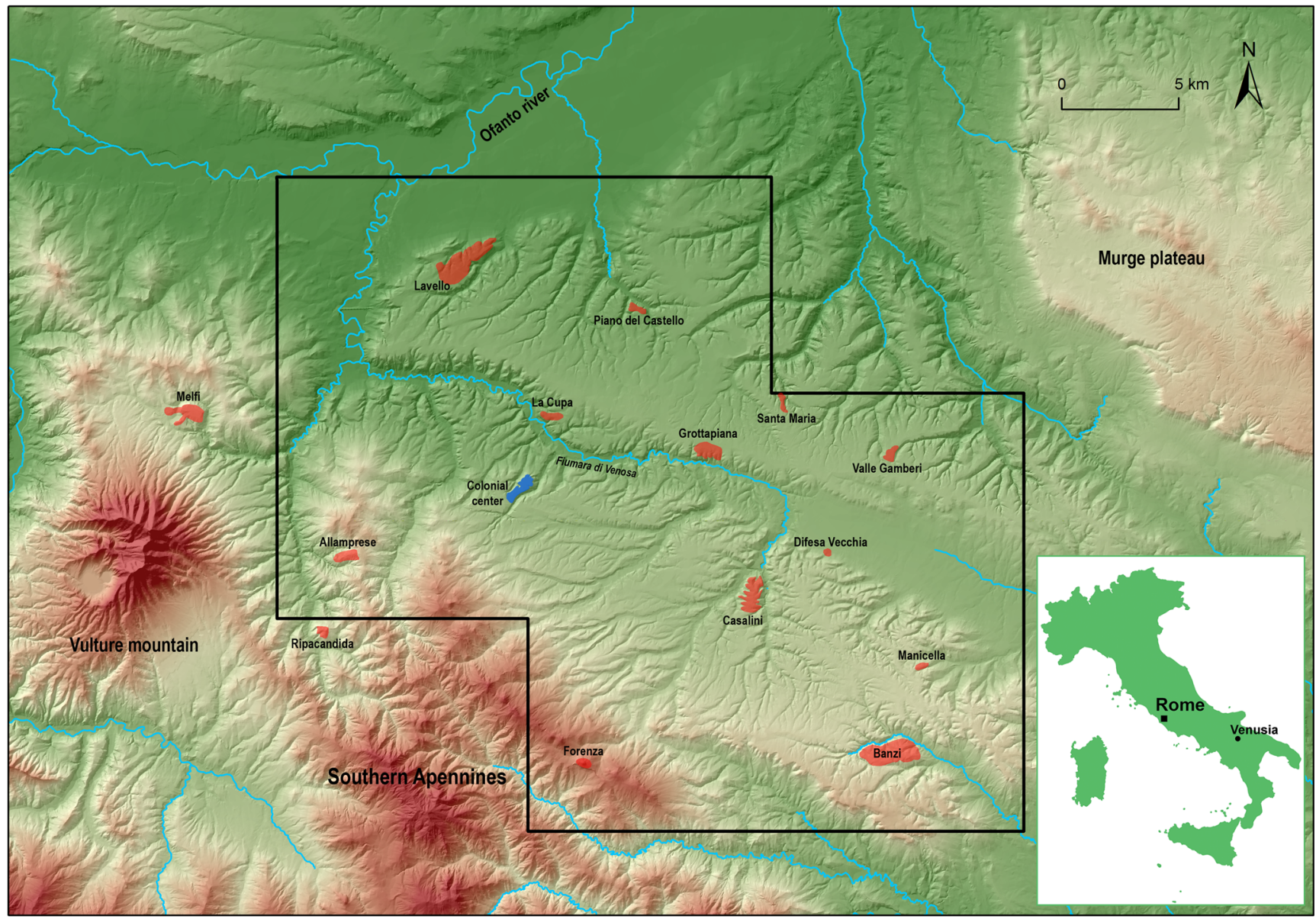

Fig. 1 Study area. The survey area is contoured in black. In red: major pre-Roman settlements; in blue: colonial center of Venusia. The raster base map is the shaded relief calculated from the 10-m resolution DEM named TINITALY/01 (Tarquini et al. 2007, 2012; Tarquini and Nannipieri 2017) and combined with an elevation color palette. Figure by Anita Casarotto
From a geomorphological point of view, this "frontier" zone is characterized by the presence of two macro topographical units: the hilly landscape (an appendix of the southeastern Apennines which extends up to the Vulture mountain) and the plateaus landscape (naturally connected to the Apulian plain through the Ofanto river). In our survey area, hills are typical of the western and south-western part, whereas large plateaus are located centrally, east-, north-, and southeastwards (Fig. 1). In Archaic and pre-Roman times, these two macro-regions most likely pertained to different sociopolitical groups. Archaeological studies suggest that the people inhabiting the major settlements of the plateau zone of this territory strongly interacted with Daunian material culture (Marchi 2010: 247-254; Bottini 2016: 10-20), while the material culture found at the settlements located in the hilly landscape demonstrates also influences of North-Lucanian traditions (emblematic is the case of the site of Ripacandida, see Bottini 1982, 2001; Marchi 2010: 35; Bottini 2016: 33-42, and some evidence may be attested also in Forenza and Banzi, see Marchi 2010: 182) (Fig. 1). Therefore, settlement strategies in the hilly landscape of our study area witnessed a mixture of influences from the surrounding areas, most clearly from both the Daunia and the North-Lucania regions.

Between these two geopolitical districts (i.e., the hillsinfluences from North-Lucania and Daunia regions and the plateaus - influences from the Daunia region), a more marginally settled area is located. Despite the identical environmental conditions (this large area consists of plateaus with the same geological and soil properties as the plateau district), it was not intensively used by pre-Roman communities (see Fig. 2). If, at first sight, natural factors do not justify the difference in patterning, we may consider that a cultural reason could be the cause of such a settlement vacuum in pre-Roman times. Perhaps this area represented a marginal or "frontier" zone between two different geopolitical districts (letter A in Fig. 2) (see discussion in De Guio et al. 1986), which could explain the relative lack of sites, and justify the probably different land use strategy. In the fourth and early third century $\mathrm{BC}$, the whole area was affected by important socio-cultural developments that have been related to the arrival of new groups of people, indicated with the name of Samnites (Bottini 1980; Marchi 

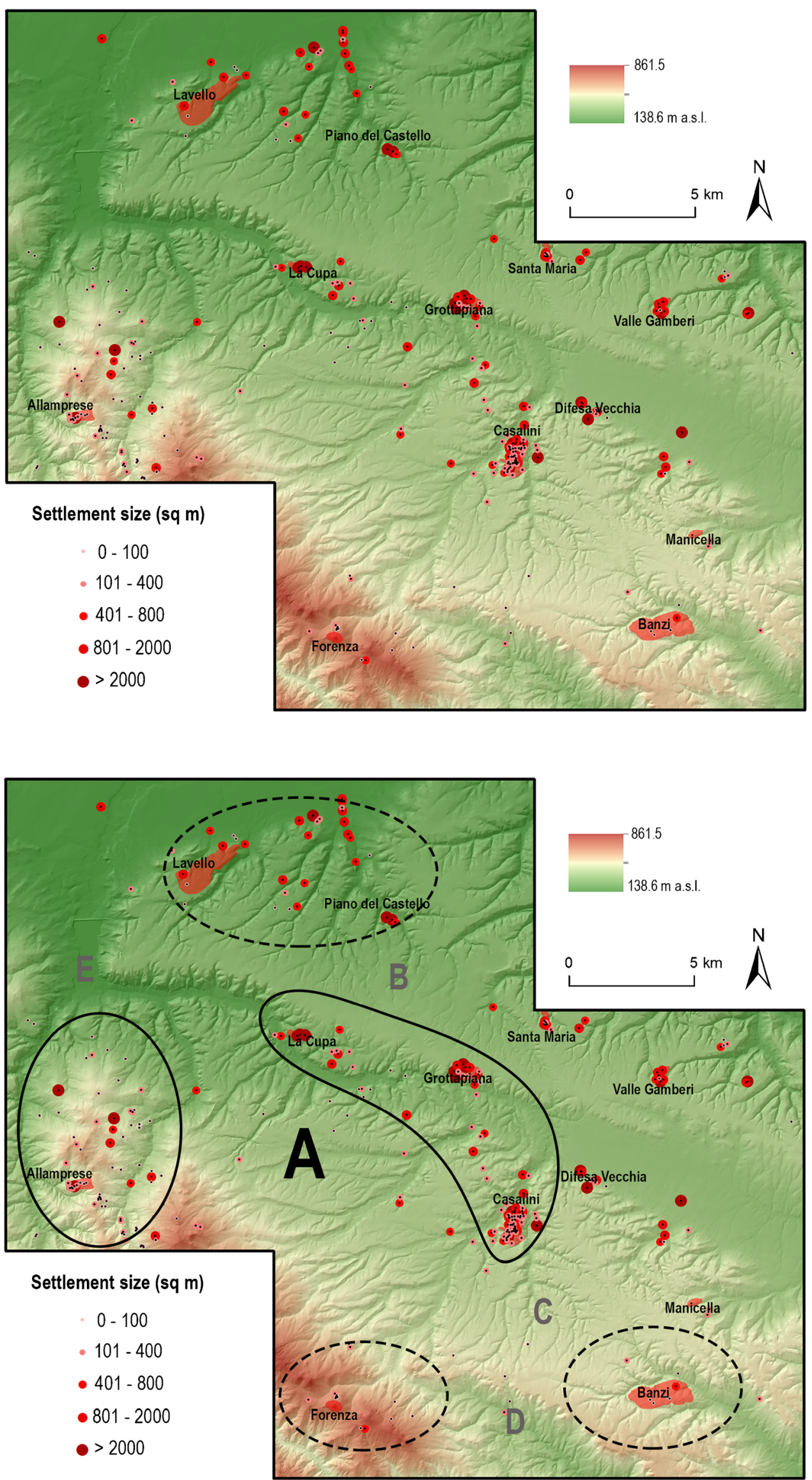
Fig. 2 Pre-Roman settlement distribution with the acronyms of the main nucleated settlements. The position of settlements is indicated by black dots. The extension of the red circles circumscribing these dots does not match with the scale of the map; they are used here only as symbols for the size of these settlements (see legend). Below, reconstruction of the pre-Roman territorial organization: the hilly and plateau pre-Roman districts are circled by black ellipses. Other possible districts within both the plateau and the hilly landscape are circled by dashed ellipses. The letter A indicates the position of the possible "frontier", marginal zone between the hilly and the plateau landscapes. The letters in gray indicate other zones where pre-Roman site density is remarkably low. The raster base map is the shaded relief calculated from the 10-m resolution DEM named TINITALY/01 (Tarquini et al. 2007, 2012; Tarquini and Nannipieri 2017) and combined with an elevation color palette. Figure by Anita Casarotto

and Sabbatini 1996: 99-100, 109-110; Sabbatini 2001: 57; Marchi 2016). Settlement density continued to be low in the marginal zones previously outlined, confirming the likely inheritance of land use strategies.

What is particularly interesting to us, however, is that the subsequent site patterning suggests that the decision on where to establish third century settlements depended strongly on the pre-colonial landscape settlement organization (see discussion in Nuninger et al. 2016). As seen in Figs. 2 and 3, third century settlements were established in the previously outlined marginal and scarcely inhabited area within the native settlement system (see also Marchi
1991; Marchi and Sabbatini 1996: 111; Marchi and Salvatore 1997: 13-14; Marchi 2010: 249). This third century settlement organization can thus be seen as an organic addition to a pre-existing situation, rather than as a radical overhaul of the settlement organization, as is usually imagined. New sites were located on the plateaus around the colonial center and some others (both new sites and some that continued) were located in the hilly landscape. The period directly after the establishment of the Latin colony thus witnesses a rural infill of settlements in a previously marginally settled zone, and the majority of these sites centered around the major settlement core of Venusia. In a sense, we may therefore see the very same principle that was noted on a peninsula-wide level by de Cazanove (2005) on the local scale, namely that colonial settlement targets relatively empty and marginal areas (cf. also Marchi and Salvatore 1997: 13; Stek 2012: 244).

Another peculiarity of the third century BC pattern must also be noted. If we look closely at its spatial distribution, it is possible to note a different settlement behavior with respect to the two geopolitical districts of the pre-Roman settlement system (see also Marchi 2004: 133). Density and distribution suggest a preference only for the hilly landscape. In the hilly landscape, there is clear continuation in occupation and further rural infill from the fourth to the third century BC (especially in the most northern
Fig. 3 Early colonial period settlement distribution with the indication of the position of previous pre-Roman settlements (gray dots delimitated by empty circles). The position of the early colonial period settlements is indicated by black dots. The extension of the red circles

circumscribing the dots does not match with the scale of the map; they are used here only as symbols for the size of these settlements (see legend). The raster base map is the shaded relief calculated from the $10-\mathrm{m}$ resolution DEM named TINITALY/01

(Tarquini et al. 2007, 2012;

Tarquini and Nannipieri 2017) and combined with an elevation color palette. Figure by Anita Casarotto

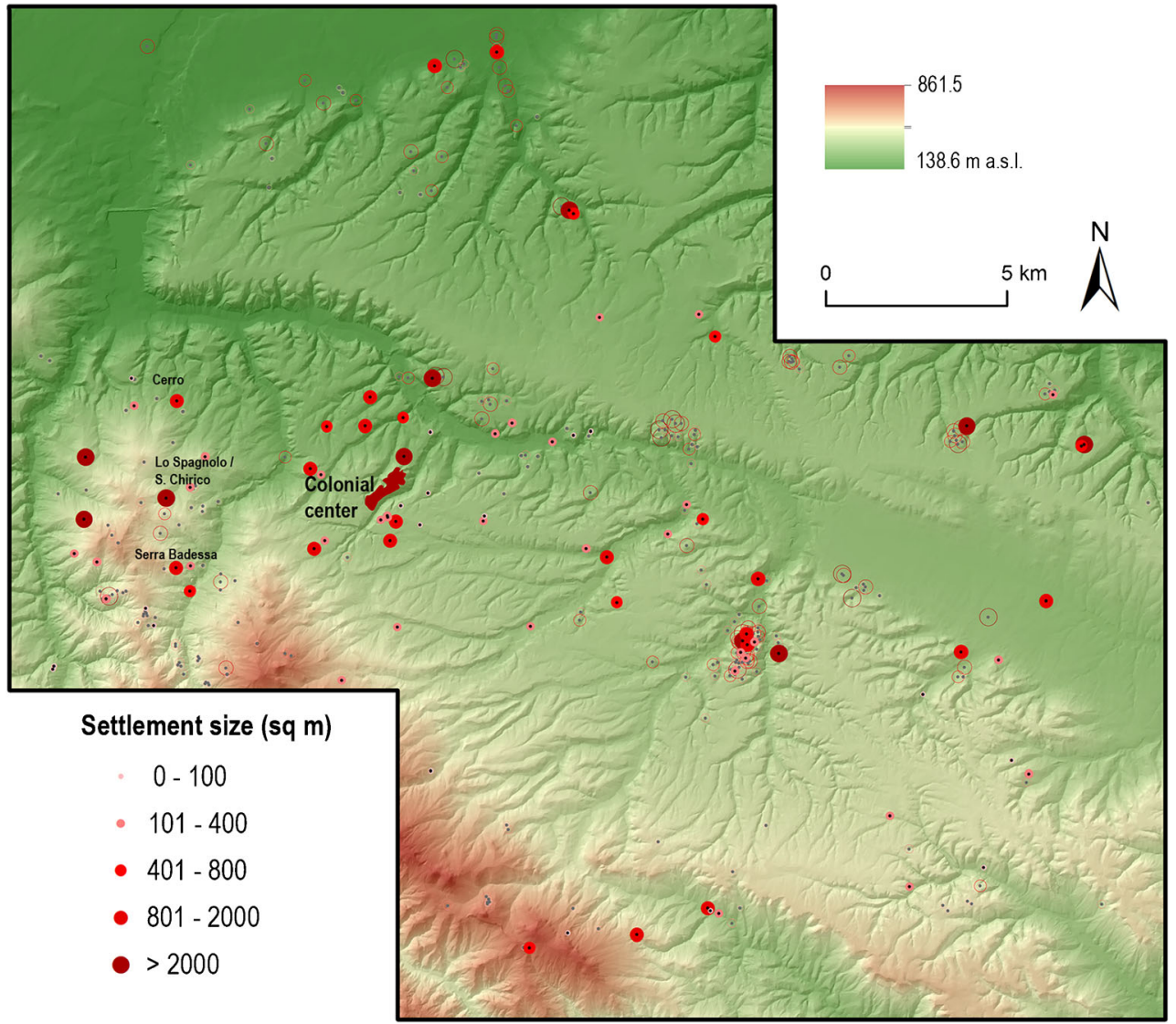


Fig. 4 Republican settlement distribution compared to the previous territorial organization. The centroids of the main preRoman nucleated villages are indicated by yellow circles. From these settlements, possible catchment areas are visualized by means of a cost analysis. The lined areas indicate the position of possible long-lasting natural or cultural "frontier" zones where site density is low from the preRoman to the Republican period (and even later). The raster base map is the shaded relief combined with the cost surface calculated from the 10-m resolution DEM named TINITALY/01 (Tarquini et al. 2007, 2012; Tarquini and Nannipieri 2017), which takes as starting points the centroids of the major pre-Roman settlements (yellow circles). Figure by Anita Casarotto

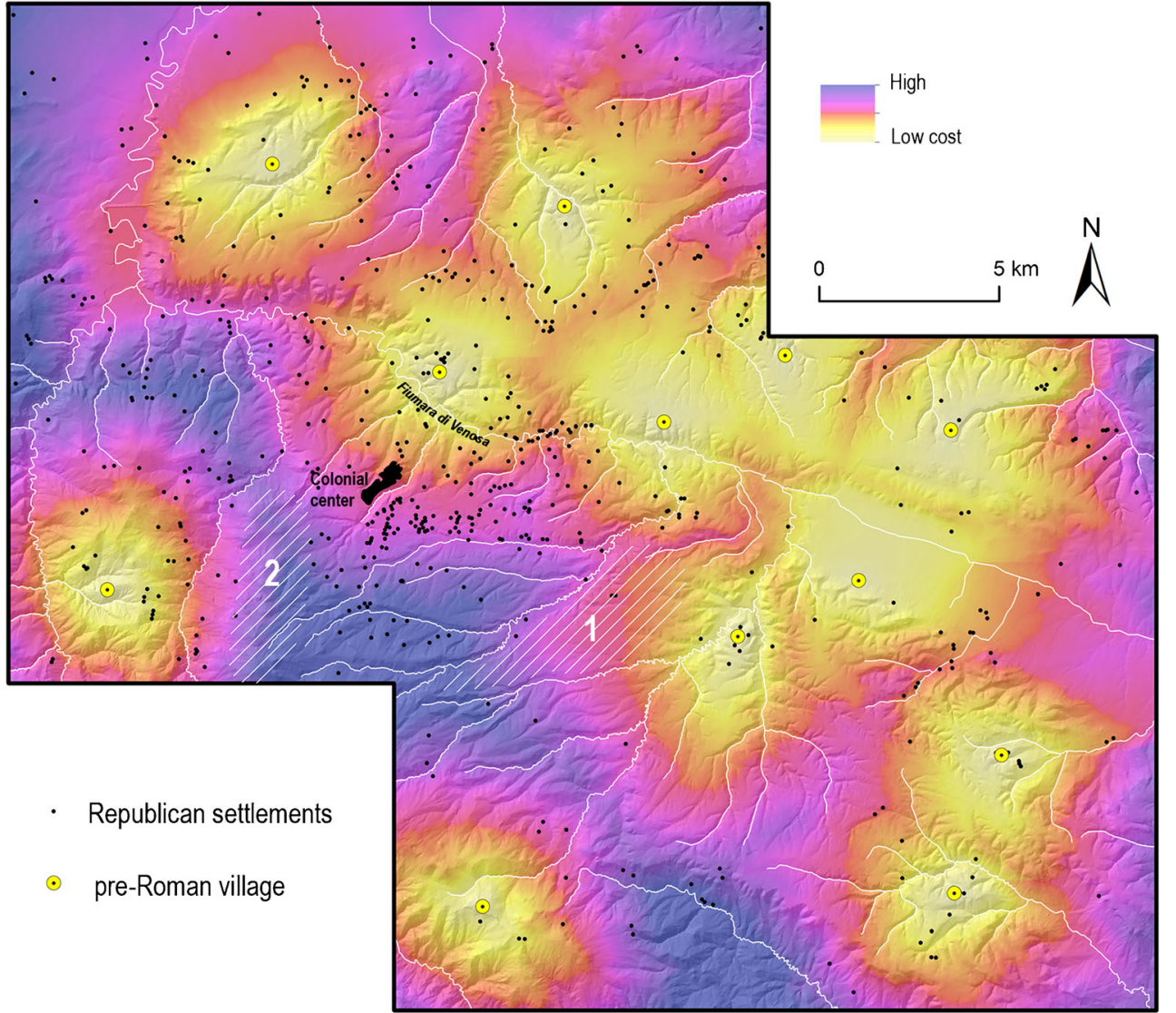

part of it, in locality Lo Spagnolo, Pezza Cicoria, S. Chirico, Serra Badessa and Cerro) (see Marchi 2010: 98-117) (Fig. 3).

The settlement continuation in the hilly landscape has been confirmed in more recent investigations as well, through a study of the black gloss pottery collected during several surveys carried out between 2013 and 2016 in the context of the LERC project (Landscapes of Early Roman Colonization, Stek and Pelgrom 2013). With these surveys, we established that one of the major nucleated villages of the pre-Roman system, Allamprese, continued to exist in the third century BC (Pelgrom et al. 2014). This situation of settlement continuity does not seem to apply to the pre-Roman plateau landscape where most villages seem to disappear fairly quickly after the establishment of the Latin colony in the area. We are currently testing this on the ground: the ongoing analyses of the material recently collected by the LERC team at the preRoman nucleated settlements of the plateau landscape (e.g., Casalini, Piano del Castello) will allow more accuracy in the future (see Pelgrom et al. 2016). From the dataset at our disposal, however, it appears that the hilly landscape continued to be occupied in the third century $\mathrm{BC}$ and seems to be more integrated into the early colonial settlement system than the plateaus landscape located to the north, east, and south-east of the survey sample area (see also Marchi and Sabbatini 1996: 114-115).
The impression given by the third century settlement sample in the plateau landscape, thus, is that the new settlements initially may have adapted themselves to a pre-existing situation by occupying the space still available. Also, more generally in the Republican period, the site patterning continues to display the characteristics of an adaptive rural infill both in the same preferred areas of the early colonial phase (hills and central plateaus) and in the marginal and less-densely settled zones of the pre-Roman settlement organization.

The Republican period rural infill, in fact, does not affect all landscape districts equally, but seems to concentrate in certain niches. Some clear trends in the use of space can be detected. For instance, certain areas remain blank from the pre-Roman to the Republican periods, suggesting perhaps the presence of natural or cultural "frontier" zones (e.g., woods, sacred places) that were respected by not being settled over time (see Fig. 4 for a possible reconstruction of some of these "frontiers"). On the other hand, in other previously unoccupied niches, we do see an infill of sites occurring in the Republican period. Moreover, the role played by the colonial urban center remains clear: the rural infill clusters around and expands from the town over time.

This clustering of Republican period sites both in previous marginal niches and close to the colonial town is displayed in Fig. 4. This image represents a simulation that models the pre- 
Roman network of major nucleated settlements, their territorial catchments, and the marginal zones and niches in between them. We conducted this analysis in TerrSet GIS by using the module "Varcost" (Eastman 2016). Territorial catchments (Vita-Finzi and Higgs 1970) were calculated on the basis of an anisotropic cost surface that takes into account as obstacles to human movement both the morphology of the terrain (slope and aspect) and the position of the main not-navigable rivers. ${ }^{1}$ The extension of each catchment area terminates when the same cost value calculated from the neighbor settlements is met (for more sophisticated ways of simulating settlement territories see Renfrew and Level 1979; De Guio 1988-1989; De Guio and Secco 1988; Wheatley and Gillings 2002: 151-159; Conolly and Lake 2006: 208-225; Ducke and Kroefges 2008).

Figure 4 illustrates that the colonial urban center, and the settlements clustered around it, are located in the largest purple/pink halo corresponding to the marginal zone between the two geopolitical districts of the pre-Roman settlement system. Interestingly, the other Republican settlements tend to cluster in smaller niches, precisely at the margins of the catchment areas of the pre-Roman nucleated settlements.

We also noted that the rural infill by Republican settlements, but also by the subsequent Triumviral ones, does not affect the entire survey sample area with the same density. In fact, the plateaus located south and east in the survey area are much less densely occupied. The Republican and Triumviral samples clearly tend to concentrate in the central plateaus (around the town), in the northern plateaus (on the other side of the Fiumara di Venosa valley), and west in the survey area. The dividing line between these two different trends in regional pattern and density can be positioned on a large plateau that we previously pointed out as one possible long-lasting "frontier" zone (see number 1 in Fig. 4).

This situation changes in the Imperial period, when sites are more homogeneously and regularly located across the entire survey area (Figs. 6 and 7) (see also Marchi 2004: 139), and also occupy those southern and eastern parts of the survey sample area that witnessed no remarkable settlement in the previous Roman periods. ${ }^{2}$ Therefore, for Imperial rural settlement strategies, the pre-existing landscape organization seems to play a minor role in location preferences.

\footnotetext{
${ }^{1}$ Rivers and streams were extracted from the hydrological system of Regione Basilicata. This data was kindly provided by the Regione Basilicata in June 2013. Data concerning the hydrography of this territory can be found in the catalog of the Geoportale of Basilicata (RSDI): http://rsdi.regione. basilicata.it

For the territory outside Basilicata, rivers and main streams were digitalized manually on the basis of topographic maps.

2 This is in line with the taking over of villa estates consisting of large Imperial settlements and other satellite productive settlements from the first century AD onwards (see also Torelli 1991: 23; Marchi 2004: 129-130; Marchi 2010: 260) which were spread homogeneously to exploit all different ecological sectors of this landscape (see discussion in White 1970: 19-20; Gabba 1977: 269-284; Torelli 1990; Carandini 1994; Capogrossi Colognesi 2002; Gualtieri 2002; Marchi 2010: 273, 281; Terrenato 2012).
}

\section{Location preference analysis}

To further test the trends highlighted before, and to see whether there are other correlations which can help explain the resulting patterns, we now describe the outcomes of the inductive location preference analysis. The technical explanation and discussion of the methods and statistical tests used for carrying out such an analysis is provided elsewhere (Casarotto, 2017). Here, we only list the detected location preferences per period and size category and highlight whether these preferences change through time. Remarkable changes in location preferences may indicate significant changes in settlement strategies, which may, at least theoretically, be linked to the historically documented colonization movements. Thus, these changes may provide a measurement for the impact of Roman colonization.

We tested for the presence of spatial correlations between site patterning and several environmental and cultural characteristics of the landscape. ${ }^{3}$ Specifically, the distribution of diachronic and hierarchical site samples was compared to altitude, slope, aspect, soil, location of dominant positions in the landscape (i.e., ridges and peaks), distance from water, distance from the city and from the major Roman roads (Fig. 5). To assess whether the impact of Roman colonization is visible starting from the early colonial sub-phase, two comparisons with these variables were carried out. The first is a macrocomparison between the generally datable pre-Roman, Republican, and Imperial settlements aimed at testing whether the settlement rationale drastically changed from the pre-Roman to the Republican period, or only later in time. The second comparison is a micro-comparison, meaning that we zoomed in on the early colonial subphase to evaluate whether the most significant divergences in distribution with the pre-Roman phase emerged in the third century BC.

\section{First comparison: Pre-Roman-Republican-Imperial settlements}

The highest variability in location preferences is exhibited by the smallest site categories (0-100 and 101-

\footnotetext{
${ }^{3}$ For this aim, we used distribution graphs (the most important are provided as Online resource) and statistical tests. Specifically, the chi-squared test (Siegel 1956: 42-47; Shennan 1988: 65-70), the Kolmogorov-Smirnov test (Siegel 1956: 47-52; Wheatley and Gillings 2002: 136-142), and the Attwell-Fletcher test (Attwell and Fletcher 1985, 1987) were applied to highlight possible significant correlations in the dataset (Kvamme 1990). A significance level $(\alpha)$ of 0.05 was selected for these analyses. For an extensive explanation of the method and lists of the results, reference is made to Casarotto (2017).
} 
1
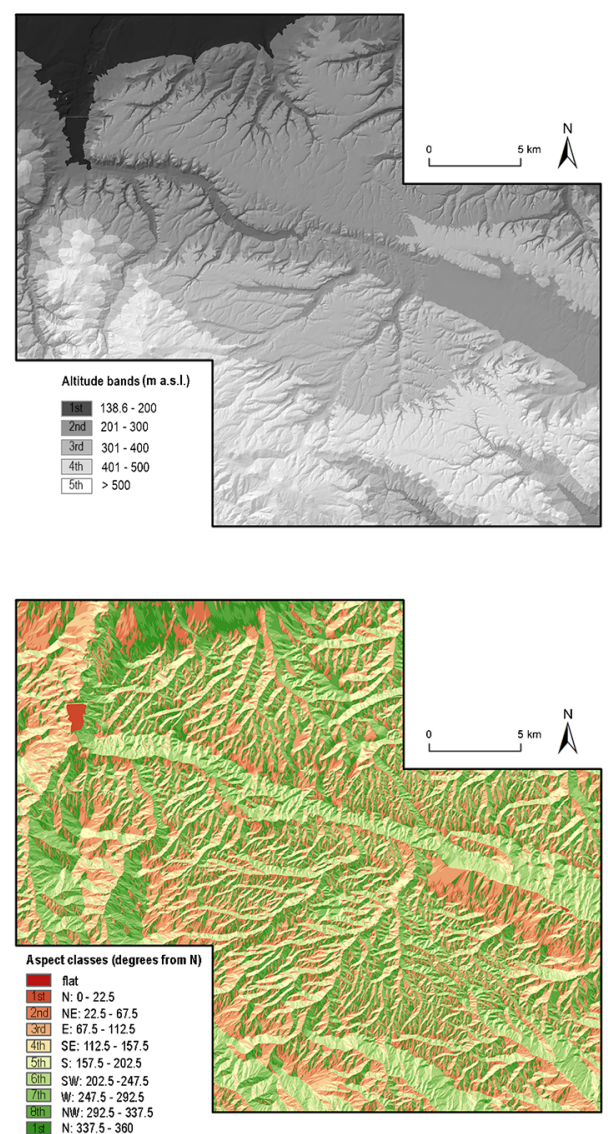

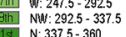

5

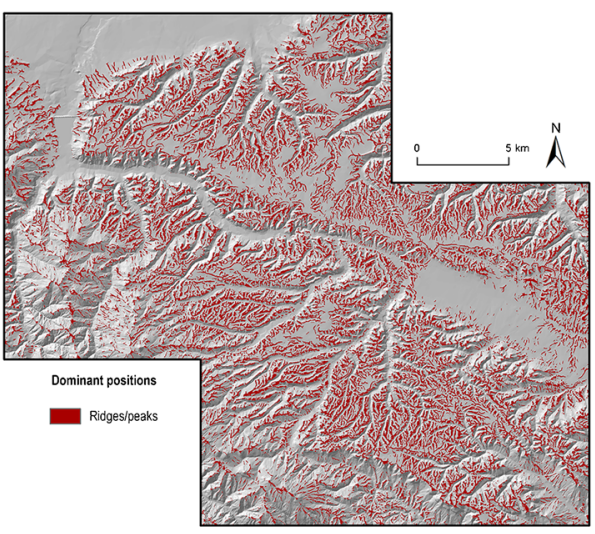

7

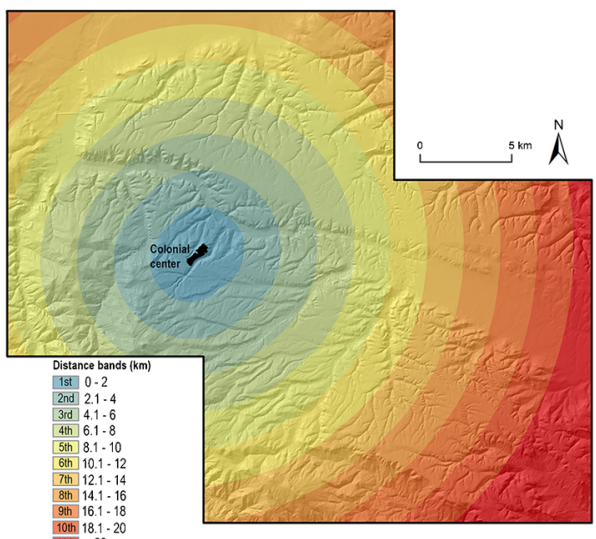

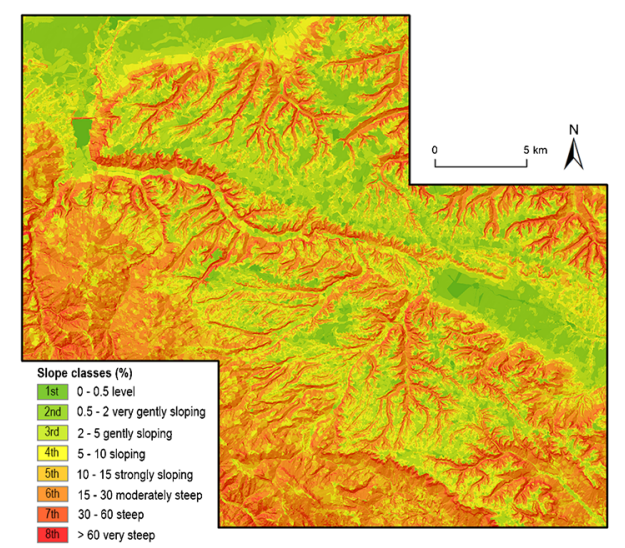

2

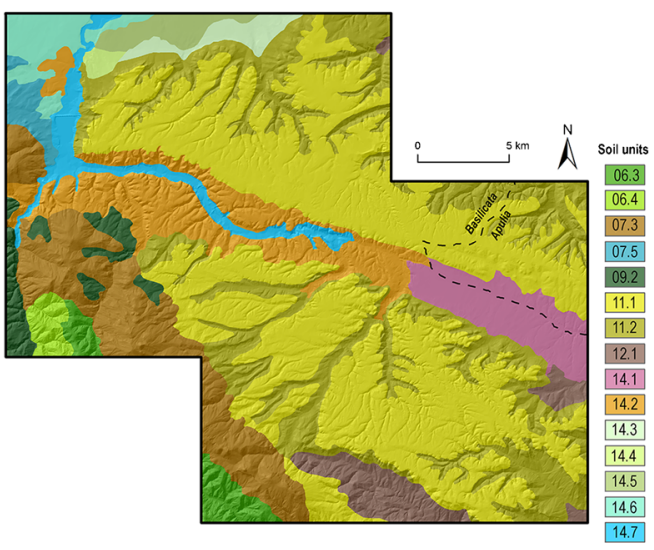

4

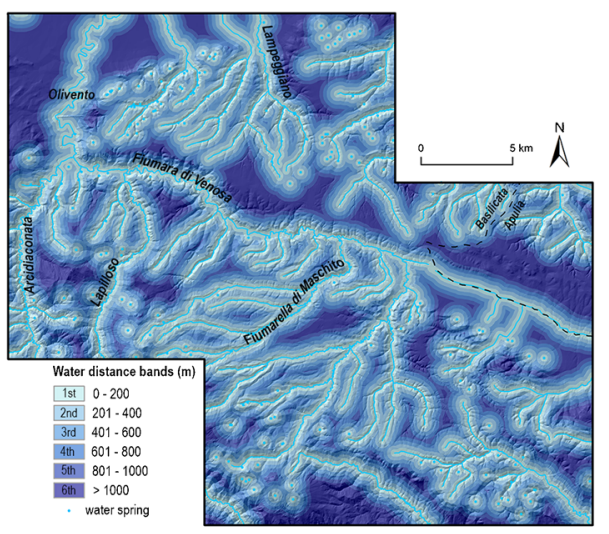

6

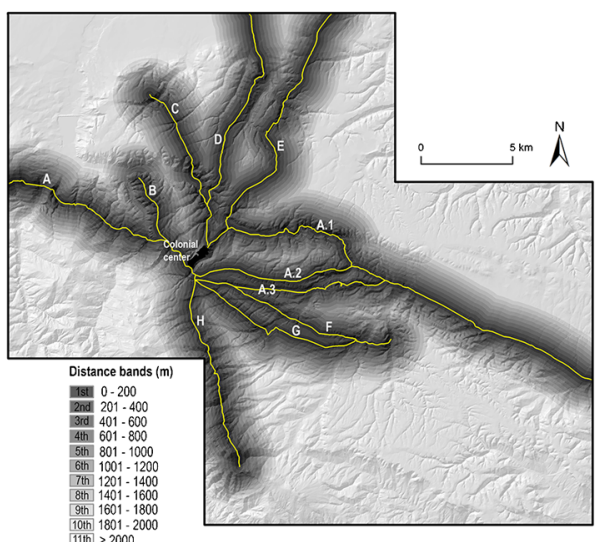

8 
4 Fig. 5 Variables considered in the inductive location preference analysis calculated in Idrisi GIS (Eastman 2012), ArcGIS 10.2.2 and LandSerf GIS (Wood 2009). Detailed information on how these variables were calculated is in Casarotto (2017). (1) Altitude (based on the 10 m-resolution DEM named TINITALY/01, Tarquini et al. 2007, 2012; Tarquini and Nannipieri 2017); (2); Slope (calculated from the 10-m-resolution DEM named TINITALY/01, Tarquini et al. 2007, 2012; Tarquini and Nannipieri 2017). The classification in slope classes is based on FAO 2006 (p. 12); (3) Aspect (calculated from the 10-m-resolution DEM named TINITALY/01, Tarquini et al. 2007, 2012; Tarquini, Nannipieri 2017). The classification in aspect classes is based on Esri 2014; (4) Soil. The base map for the territory within the administrative borders of the Basilicata region is the soil map of the Regione Basilicata (1: 250,000) (Ufficio Produzioni Vegetali e Silvicoltura Produttiva - Dipartimento Agricoltura, Sviluppo Rurale, Economia Montana - Regione Basilicata). Outside this territory soil properties were reconstructed (for further information see note 4 of this paper); (5) Location of dominant positions in the landscape (calculated from the 10-m-resolution DEM named TINITALY/ 01, Tarquini et al. 2007, 2012; Tarquini and Nannipieri 2017); (6) Distance from water sources (main rivers, main streams, and perennial water springs) (see also note 1 of this paper); (7) Distance from the town of Venusia; (8) Distance from (Roman) roads. Figure by Anita Casarotto

$400 \mathrm{~m}^{2}$ settlements) that have the most typical and diverging distribution in the different periods with respects to the variables considered in this analysis. On the other hand, larger settlement types have, in general, similar location preferences, independent of the period. The similar preferences attested by the largest settlements are mostly dependent on the fact that there exists a direct relationship between settlement size and survival rate: larger settlements very often attest continual occupation in several phases whereas the smaller site types have a shorter life span (usually one phase of occupation) and attest a higher variability in location preferences.

When analyzing the totality of sites per period, we noted a divergent preference of ecological districts in the preRoman and Republican phase. These different land units can be outlined by different altitude bands and soil conditions. The problem we want to tackle here is whether this difference in preference was possibly dictated by the more favorable soil types and geomorphological conditions characterizing the different land units. Pre-Roman settlements tend to concentrate on the 4th and 5th altitude band (and avoid the 1st one), and they seems to be especially attracted by soil unit 6.3 and 6.4 in the hilly landscape (see Table 2). The Republican settlement system, instead, preferentially clusters in the plateau landscape (quite significantly in the 3rd altitude band), which is mainly characterized by the presence of soil unit 11.1. As suggested in the previous descriptive analysis, this clustering may be explained as a result of cultural constraints rather than as a function of natural factors. Here, we want to further test this assertion.
Based on the soil map of the area (Regione Basilicata, $1: 250,000),{ }^{4}$ the detected location preferences cannot be justified by the presence of more favorable soils. ${ }^{5}$ The sandy conglomeratic soils (unit 11.1), on which a majority of Republican sites are found, are not particularly suited for arable farming (but see further discussion in Van Joolen 2003) and, due to the abundant presence of conglomeratic pebbles coming from the bed rock, are also quite difficult to work with basic tools (Frayn 1979; Spurr 1986; Goodchild 2007: 147). Interestingly, even the small Republican settlements (i.e., possibly mononuclear colonists' farms, Marchi and Sabbatini 1996: 111-115) do not exhibit significant correlations with those land units that, for their good properties (high/medium fertility and high/medium workability, see Table 2), might have been more suitable for carrying out subsistence agriculture (tracks of these 'unjustified' empty spaces in the Republican settlement pattern have been already noted by Marchi and Sabbatini 1996: 114; Sabbatini 2001: 71). It seems that the choice of preferentially settling this district in the Republican period was dictated by other constraints, such as indeed cultural ones, as we will discuss in more detail further below.

In addition to the influence of the previous territorial organization, another important cultural element is the colonial urban center. A significant preference to stay close to the main colonial settlement is clear for the Republican settlements (see also Marchi and Sabbatini 1996: 112-114; Marchi 2004: 133). The first two distance bands $(0-4 \mathrm{~km})$ have a significantly high density of sites, independently from the size category (only the largest Republican settlements $->2000 \mathrm{~m}^{2}$ - have a more scattered distribution with respect to the center). Additionally, (Roman) roads departing from or crossing the center (for a reconstruction see Fig. 9) correlate with settlement density: again, a significantly high density of Republican

\footnotetext{
${ }^{4}$ Ufficio Produzioni Vegetali e Silvicoltura Produttiva-Dipartimento Agricoltura, Sviluppo Rurale, Economia Montana-Regione Basilicata. Data and legend can be found here: http://www.basilicatanet.it/suoli/index. $\mathrm{htm}$ (credits: http://www.basilicatanet.it/suoli/credits.htm) and in the catalog of the Geoportale of Basilicata (RSDI): http://rsdi.regione.basilicata.it. The shapefile of the soil map of Basilicata was kindly provided by Regione Basilicata in May 2013.

The outmost east corner of the survey sample area belongs to the Apulia Region. The soil information for this small zone was inferred by the first author (AC) on the basis of the physiographic and geological conditions. The geological maps of this area (Carta geologica d'Italia 1: 500,000 - Geoportale Nazionale-Ministero dell'Ambiente e della Tutela del Territorio e del Mare, and Carta geologica d'Italia 1: 100,000-Foglio 188, Servizio Geologico d'Italia) were controlled to map the soil units in this zone: since the geomorphological and geological characteristics of this area are the same of adjacent soil units (i.e., 11.1, 11.2, and 14.1; see also the Carta geologica d'Italia 1: 100,000 - Foglio 175 and 187, Servizio Geologico d'Italia), this small portion of the survey area was classified accordingly, using these soil types (see Fig. 5).

${ }_{5}^{5}$ It is important to underline, however, that the present natural conditions and the present distribution of soil types may be different to those which existed in the past. Also, the scale of the soil map might have influenced our analysis in certain zones of the landscape.
} 


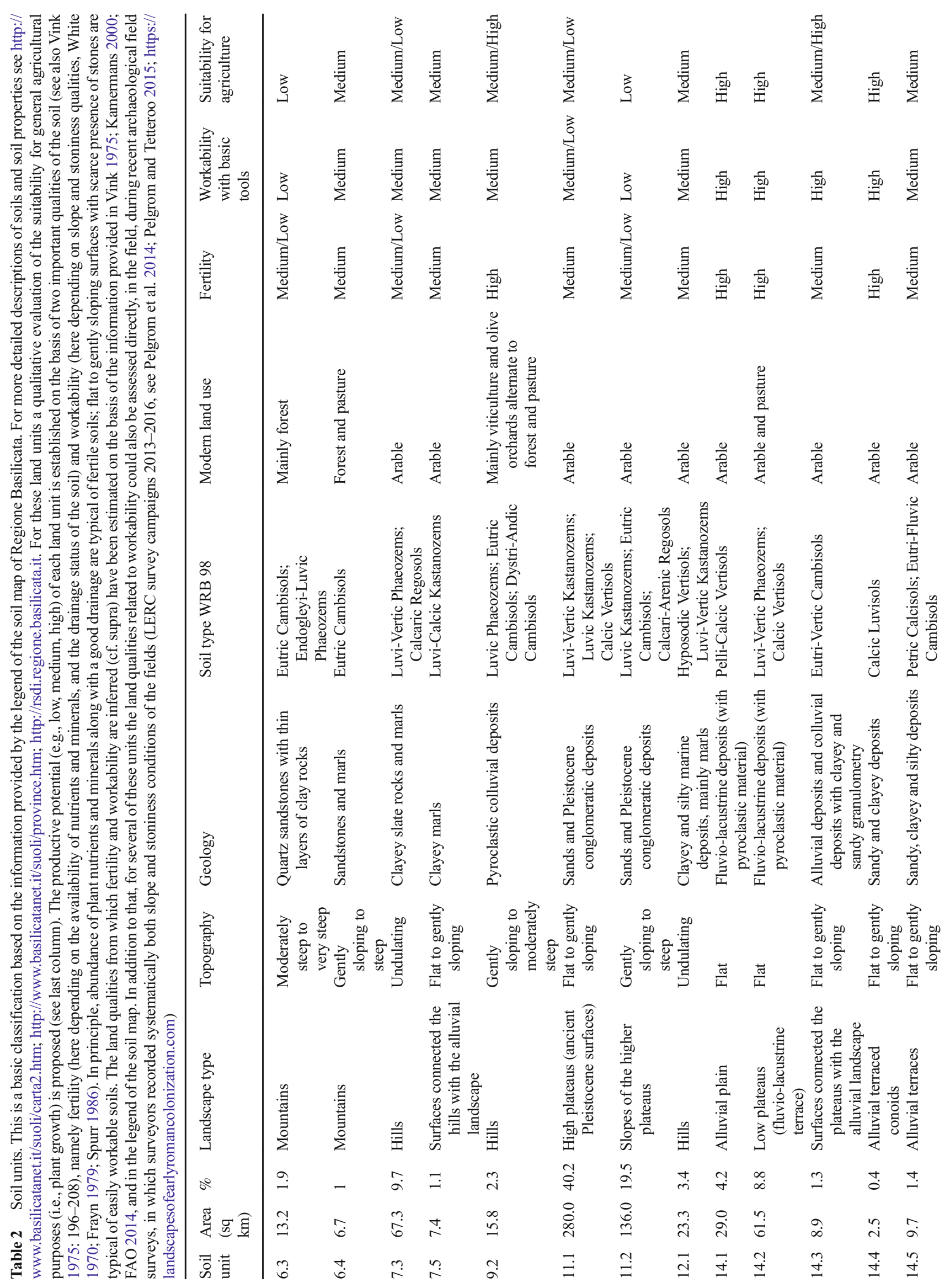


sites is attested in the first two distance bands $(0-400 \mathrm{~m})$ but the largest Republican settlements are more spread out across the territory. The colonial urban center displays a correlation with later settlements as well (i.e., Late RepublicanTriumviral and Imperial settlements), but this influence decreases significantly especially in the Imperial period. Imperial settlements are more homogeneously distributed with respect to the distance from the center (see also Marchi and Sabbatini 1996: 117-123; Sabbatini 2001: 72-75; Marchi 2004: 139; Marchi 2010: 43). A weaker correlation is observed for the distance from a (Roman) road as well (cf. Marchi 2010: 281).

Previously, we noted a lack of interest in settling the best land units in terms of fertility and workability during the Republican period. This situation seems to change in the Triumviral but, especially, in the Imperial period. As a matter of fact, at this moment in time, a significantly high concentration of settlements is attested in correspondence with highly fertile alluvial and volcanic soils (units 14.2 and 9.2). Interestingly, the preference for volcanic soils is also displayed by the smallest Imperial sites. Possibly, this preference can be related to strategic or specialized land-use practices adopted during this period of time. Unfortunately, based on the data available, it is impossible to be more precise about which type of cultures were more likely to have been cultivated here (for hypothetical reconstructions in Roman contexts see the land evaluation analyses by Van Joolen 2003; Goodchild 2007). An indication of the most suitable type of crops may, however, be deduced from the modern land use: today, in these portions of the landscape, olive groves and vineyards are grown because of the optimal soil characteristics for these crops.

To conclude, the altitude and soil variables are the environmental factors exhibiting the clearest difference in location preferences between pre-Roman, Republican and Imperial periods (Figs. 6 and 7). The other natural factors (i.e., slope, aspect, preference for dominant positions, and distance from water) affect settlement distribution quite uniformly across the various periods. Indeed, all settlement samples have similar distributions with respect to slope and aspect conditions of the terrain (see also the graphs provided as Online Resource). However, since a high number of pre-Roman settlements is located on the hills, we noticed some differences in slope values, which are however not statistically significant (Casarotto 2017).

Dominant positions (ridges and peaks) attract settlement interests in the pre-Roman, Republican, and Imperial periods (but the larger settlements of these periods do not seem to be particularly attracted by such locations, probably because of their large extent which required open spaces such as plateaus). The distance from main rivers, main streams, and perennial water springs seems to be a factor that has been taken into consideration when deciding where to locate a settlement. As a general trend, sites tend to be located at a certain distance from rivers (probably due to the risk of flooding at the nearby 


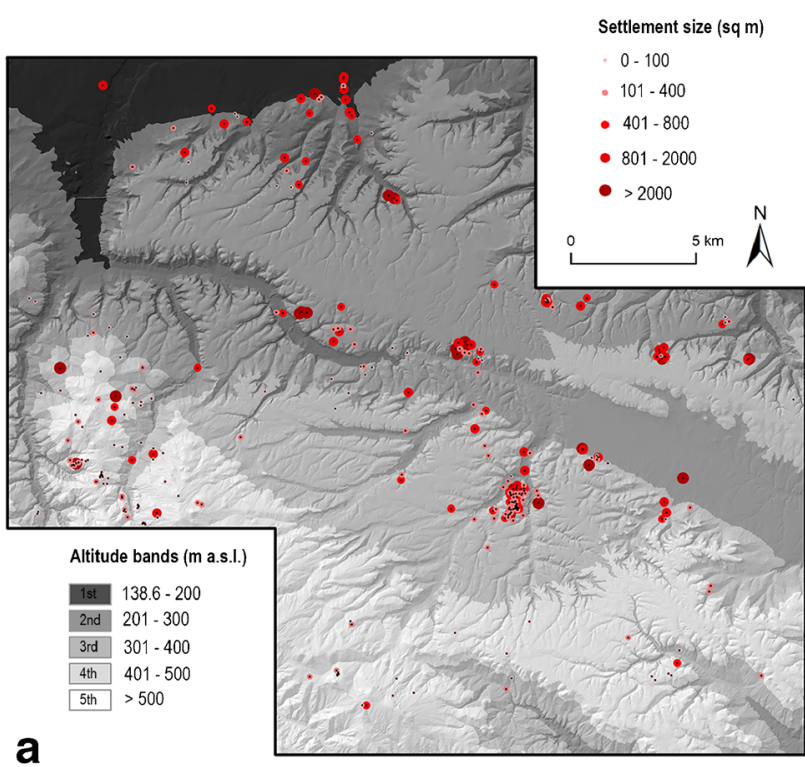

a

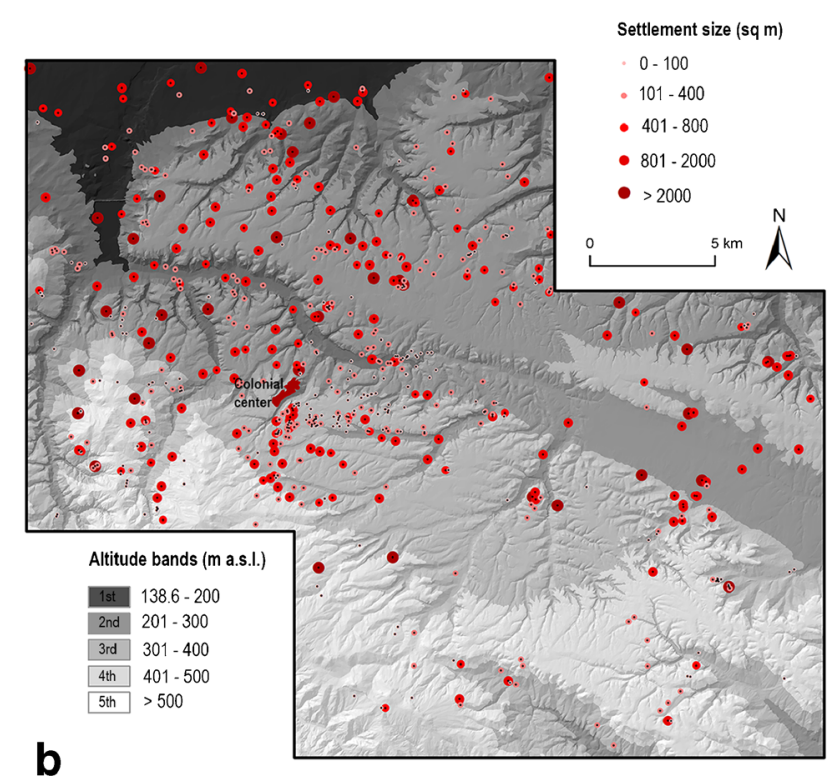

b

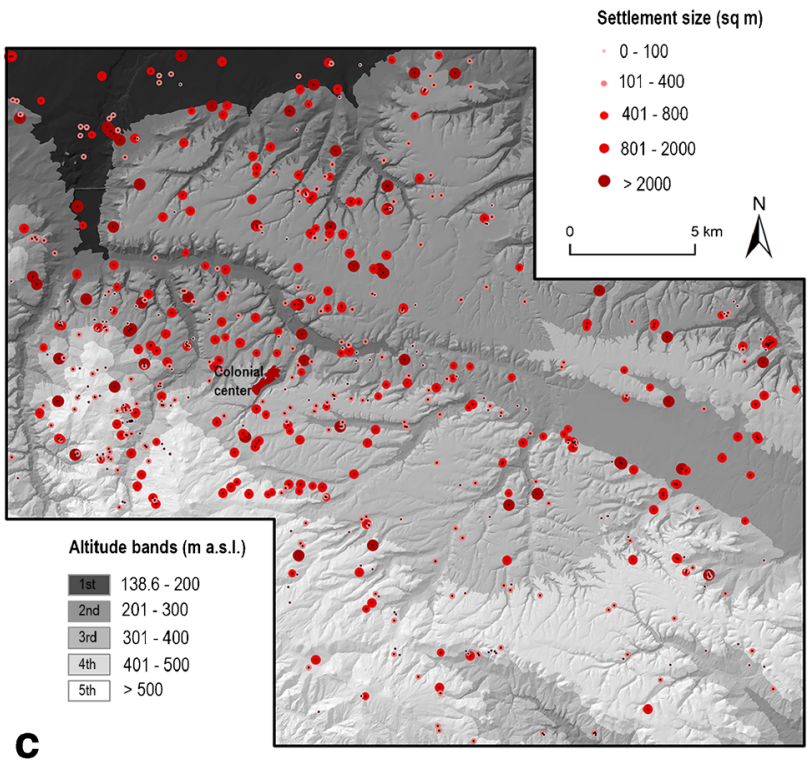

Fig. 6 Pre-Roman (a), Republican (b), and Imperial (c) settlement distributions compared to the altitude variable. The position of the settlements is indicated by black dots. The extension of the red circles circumscribing the dots does not match with the scale of the map; they are used here only as symbols for the size of these settlements (see legend). The raster base map is the shaded relief calculated from the 10-m resolution DEM named TINITALY/01 (Tarquini et al. 2007, 2012; Tarquini and Nannipieri 2017). Figure by Anita Casarotto

locations) but close enough to reach them easily. Settlements thus tend to avoid the farthest distance bands and to favor the second distance band (200 to $400 \mathrm{~m}$ from a water source). This is especially highlighted by both the smallest Republican settlements $\left(0-100 \mathrm{~m}^{2}\right)$ and by the small preRoman settlements $\left(101-400 \mathrm{~m}^{2}\right)$. We conclude that a regular water supply is an important factor for settlement purposes in all historical periods considered in this analysis.

\section{Second comparison: Pre-Roman-New settlements in the early colonial period-Early colonial period settlements}

In this section, we aim to point out early colonial period location preferences to assess significant differences (if any) with the pre-Roman settlement distribution. No clear differences between the location preferences of pre-Roman and early colonial period settlements were detected with the environmental variables considered in this analysis (e.g., altitude, slope, distance from water sources). The only clear change in settlement strategies from the pre-Roman to the early colonial period can be related to the colonial central place. There is a clear tendency by new early colonial period settlements to cluster around the center of Venusia (a significant preference is attested for the first distance band: $0-2 \mathrm{~km}$ from the center). New early colonial period sites may be attracted by roads as well (see graphs in the Online Resource). Again, we observed that cultural variables play the most influential role in settlement strategies during the early colonial period (see Figs. 8 and 9).

Cultural variables thus seem key factors not only on the peninsular scale (De Cazanove 2005) and regional scale (Marchi and Sabbatini 1996: 115; Stek 2012) but also on the local scale, where the colonial center and, to a lesser extent roads, influence the internal logistical structure of the early colonial period settlement pattern. Therefore, we conclude that, contrary to what is conventionally suggested, the pre-colonial settlement organization and the colonial center are the most influential factors in early colonial period settlement strategies, instead of soil and other environmental conditions.

\section{Conclusions}

In order to understand the settlement development of the area around the town of Venusia, we carried out two different 

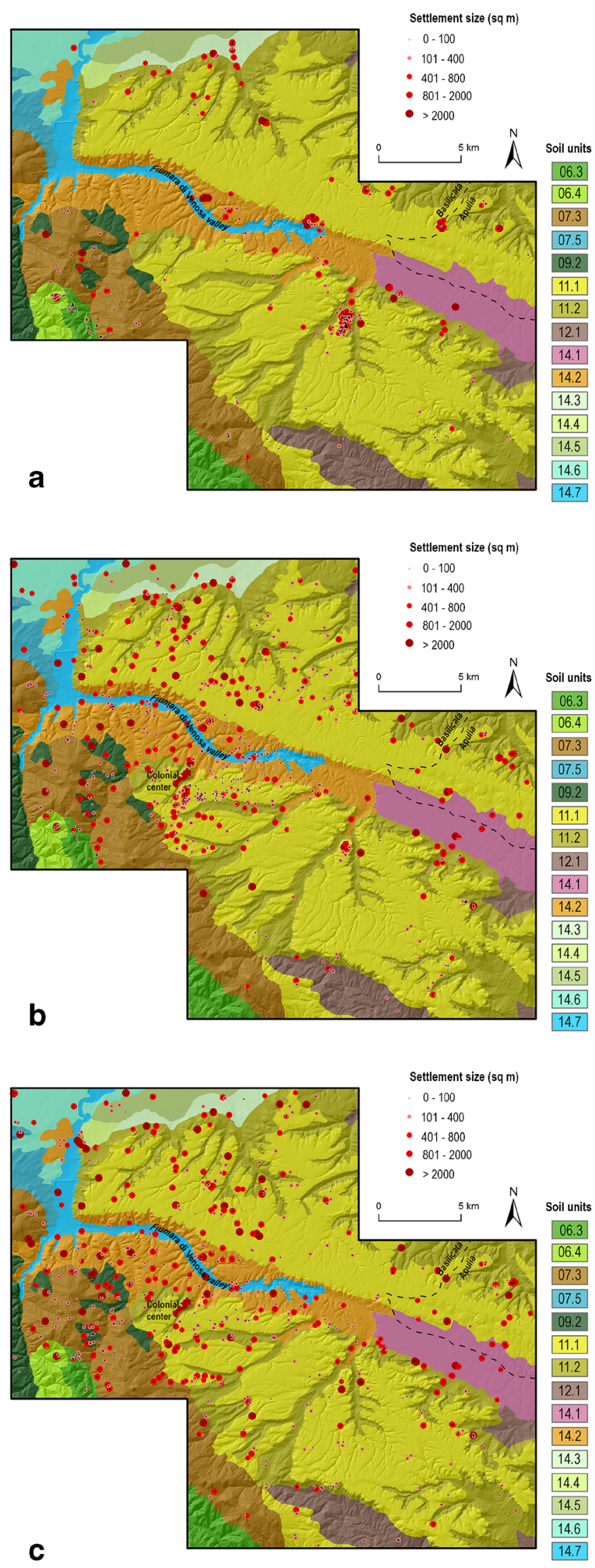

Fig. 7 Pre-Roman (a), Republican (b), and Imperial (c) settlement distributions compared to the soil variable. The position of the settlements is indicated by black dots. The extension of the red circles circumscribing the dots does not match with the scale of the map; they are used here only as symbols for the size of these settlements (see legend). The base map for the territory within the administrative borders of the Basilicata region is the soil map of the Regione Basilicata (1: 250, 000) (Ufficio Produzioni Vegetali e Silvicoltura Produttiva-Dipartimento Agricoltura, Sviluppo Rurale, Economia Montana-Regione Basilicata). Outside this territory, soil properties were reconstructed, for further information see note 4 of this paper. The raster base map is the shaded relief calculated from the 10-m resolution DEM named TINITALY/01 (Tarquini et al. 2007, 2012; Tarquini and Nannipieri 2017). Figure by Anita Casarotto

analyses to investigate how site patterning evolved over time. In both analyses, we focused particularly on those historical moments that, according to the literary sources, witnessed the arrival of groups of Roman settlers who colonized this territory. Based on the results from the first descriptive analysis, we therefore conclude that the pre-existing territorial organization of the pre-Roman settlement system determined to a large extent the choice of the area where the first third century colony was established. The most influencing factors in early colonial period settlement strategies are therefore not to be sought in favorable conditions of the natural environment, but rather in cultural constraints. The newly developing settlement organization complemented, rather than replaced the existing territorial organization, by adaptively filling in the relatively scarcely settled portions of the landscape, corresponding to the marginal niches at the borders of the catchment areas of pre-Roman nucleated settlements and the large empty zone consisting of plateaus located centrally in the survey sample area. The weak effect of natural factors (e.g., soil) on early colonial period settlement developments has also been confirmed by means of the second inductive analysis of location preferences. In addition, through this analysis, we established that the internal structuration of the settlement infill also depended mostly on cultural factors. Most evidently, the distance from the main colonial settlement-core had an important role to play in rural settlement location preferences and, to a lesser extent, the distance from roads as well.

Contrary to what has been proposed in previous debates on Roman colonization, our analyses have made clear that the pre-existing settlement organization had a determining role in the development of colonial period settlement strategies. Of course, it is not possible from survey evidence to link the new settlements directly to colonization. But the gradual and adaptive settlement development in the colonial landscape we saw, certainly challenges the conventional notion of a radical break with previous settlement organization and its settlers (contra e.g. Settis 1984; see also the discussion in Terrenato 2001, 2007; Bradley 2006; Van Dommelen and Terrenato 2007; Roppa and Van Dommelen 2012; Stek et al. 2015; Sewell 2016; Vermeulen 2017). 

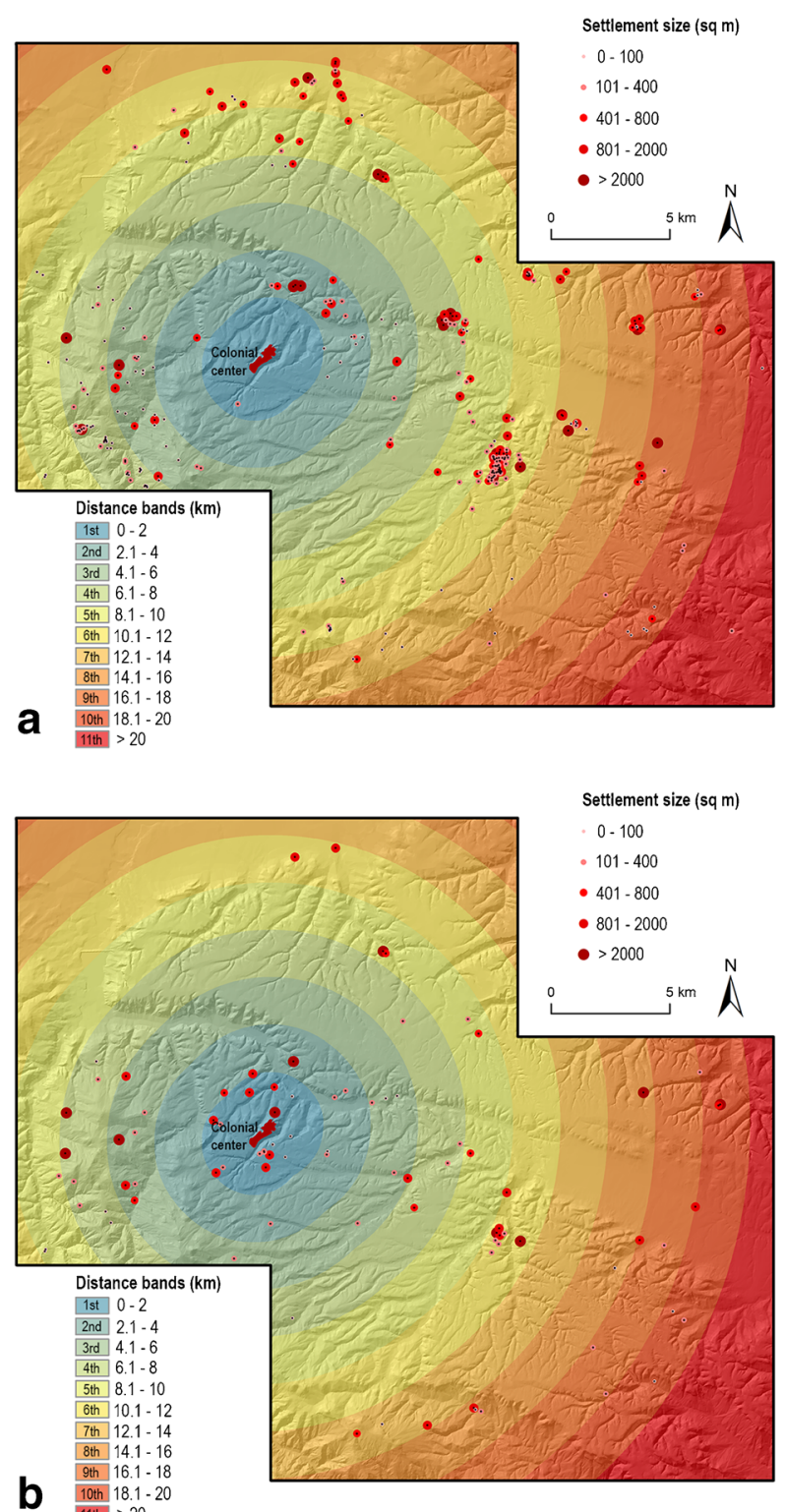

b 10 th $18.1-20$

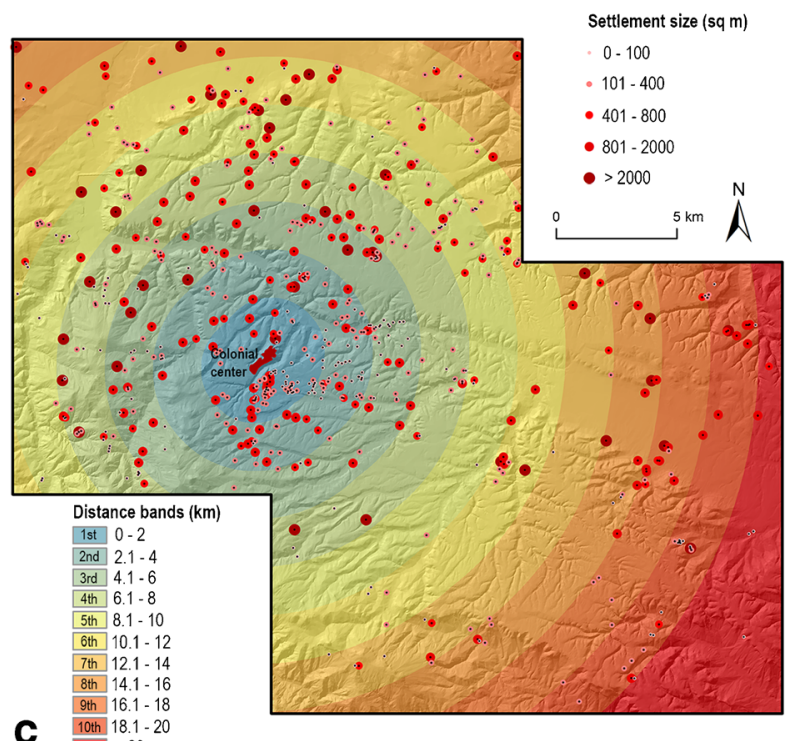

Fig. 8 Pre-Roman (a), Early Colonial (b), and Republican (c) settlement distributions compared to the distance from the colonial center. The position of the settlements is indicated by black dots. The extension of the red circles circumscribing the dots does not match with the scale of the map; they are used here only as symbols for the size of these settlements (see legend). The raster base map is the shaded relief calculated from the 10-m resolution DEM named TINITALY/01 (Tarquini et al. 2007, 2012; Tarquini and Nannipieri 2017). Figure by Anita Casarotto

This more adaptive and organically growing settlement scenario might also explain the presence of localized densities of Republican settlements at the margins of the pre-Roman settlement system we noted in previous work (for Aesernia see Stek et al. 2015; for a comparison between Venusia, Aesernia and Cosa see Casarotto et al. 2016). Due to the high isotropy in natural conditions of the plateau area, this cultural trend is particularly evident in the plateau landscape (see Fig. 4). In the hilly landscape such a clustering trend at the margins is not immediately visible, because the high variability in morphological conditions characterizing this unit hampers a clear discrimination of marginally settled niches. However, when we look more carefully at the patterning, we may also recognize the same trend here. Indeed, we noted that Republican concentrations of sites tend to cluster in previously less densely settled zones, just in front of prior nucleated pre-Roman settlements (e.g., in Pezza Cicoria, Serra Badessa, Lo Spagnolo) (see Marchi 2010: 253-255 for a different explanation). For the Republican period, therefore, we conclude that the dominant type of regional pattern consists of a balanced rural infill of sites clustered in few scattered zones only marginally occupied in the previous period. Hypothetically, if we assume all Republican period settlements were established in the early colonial phase by people of Roman origin, data patterning suggests that they probably adapted to a pre-existing situation by preferentially occupying the available space, regardless of its natural properties. The third century as well as the second century $\mathrm{BC}$ waves of Roman colonization, apparently, did not trigger a complete restructuring of the territorial organization, as is usually suggested.

In the late first century $\mathrm{BC}$, natural factors started to play a more important role in allocation strategies. In the Triumviral period, indeed, the only remarkable change in location preferences we observed from the Republican phase is a preference for more fertile soils. However, in this period, cultural constraints also still seem to be more influential with respect to territorial organization. As a matter of fact, a further rural infill in correspondence to the same districts favored by previous Republican settlements could be noted. This changed quite drastically only in the Imperial period. As Marchi and Sabbatini observed, starting from the first century AD, the settlement distribution is more homogeneously scattered across the entire survey sample area than it has ever been before (Marchi and Sabbatini 1996: 117-123; Sabbatini 

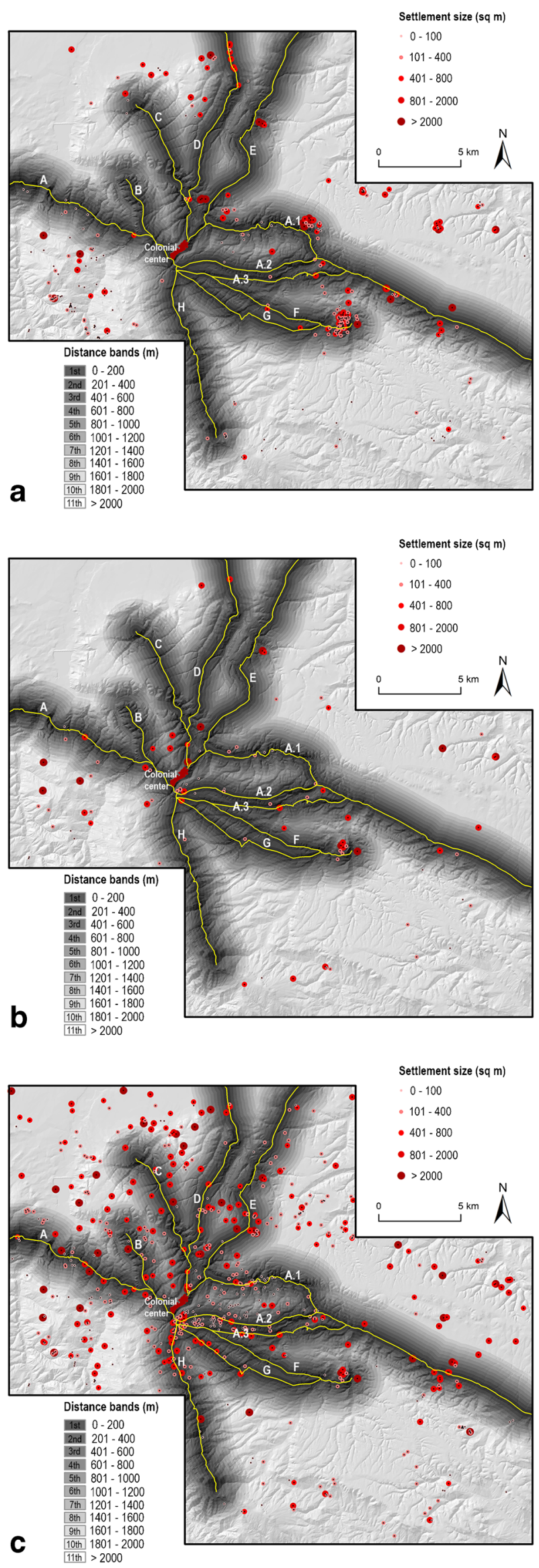

Fig. 9 Pre-Roman (a), Early Colonial (b) and Republican (c) settlement distributions compared to the distance from a Roman road. The routes have been digitalized on the basis of the information and maps reported in Salvatore 1984 (pp. 17-21), Marchi and Sabbatini 1996 (pp. 125-127), Sabbatini 2001 (pp. 78-80) and Marchi 2010 (pp. 279-285). A: Via Appia; A.1: alternative route of the Via Appia (Marchi and Sabbatini 1996: 125); A.2: segment of the Via Appia (Marchi and Sabbatini 1996: 125-127, see also Marchi 2010: 279-285); A.3: segment of the Via Appia (Vinson 1979; Marchi and Sabbatini 1996: 125-127); B: Via Venusia - Herdonias (Salvatore 1984: 17-21; Marchi and Sabbatini 1996: 125-127); C: Via Venusia - Forentum (Marchi and Sabbatini 1996: 125-127); D: road parallel to the Lampeggiano river (Sabbatini 2001: 78-80); E: via Venusia - Canusium (Sabbatini 2001: 78-80). F and G: via Venusia - Bantia (Buck 1981; Marchi and Sabbatini 1996: 125-127); H: via Herculia (Buck 1971; Marchi and Sabbatini 1996: 125 127). The raster base map is the shaded relief calculated from the $10-\mathrm{m}$ resolution DEM named TINITALY/01 (Tarquini et al. 2007, 2012; Tarquini and Nannipieri 2017). Figure by Anita Casarotto

2001: 72-75; Marchi 2004: 139; Marchi 2010: 43). The colonial center seems to be less important for the site locations; Imperial settlements exhibit a preference for the most favorable natural conditions for settlement and agriculture (e.g., fertile soils, ridges, and peaks).

To conclude, in this paper, we have cast new light on the evolution of the rural territory around the Roman town of Venusia. The main point we reached through our analyses is that settlement of the colonial period was less invasive and grew much more organically with respect to the pre-existing settlement patterns than is usually assumed. Indeed, the Roman colonization of the area in the third century $\mathrm{BC}$ does not seem to have entailed a drastic reshaping of the previous territorial organization. Settlement location in the colonial period was directed more by the pre-existing sociopolitical organization of this territory, than by its environmental conditions (such as favorable soils). Regardless of whether the new sites of the colonial period can actually be linked directly to Roman settlers, or to indigenous or mixed strategies, this conclusion strongly questions traditional theories about Roman colonial settlement organization. In the past, scholars have lent great importance to natural constraints and in particular favorable soils for certain types of agriculture, and have disregarded the influence of native communities and their territorial organization as being irrelevant or indeed swept away by the Roman conquest (Salmon 1969; White 1970; Brown 1980; Rathbone 1981; Celuzza and Regoli 1982; Carandini et al. 2002: 108-110; see the critics against this view by Terrenato 2001, 2007; Bradley 2006). Only in the first century BC, and above all in the first century $\mathrm{AD}$, we see remarkable divergences from previous settlement patterns. Only at that point, natural conditions started playing a more important role in settlement strategies.

Acknowledgements The present analysis on the colonial landscape of Venusia forms part of the broader Landscapes of Early Roman Colonization Project (LERC) funded by the Netherlands Organization for Scientific Research (NWO project number: 360-61-040). The LERC 
project is supported by the Faculty of Archaeology of Leiden University and the Royal Netherlands Institute in Rome (KNIR). The Venusia part of the project consists moreover of a close collaboration with prof. M.L. Marchi, of the University of Foggia, whom we thank warmly for her advice and her invaluable expertise. We also thank the Soprintendenza Archeologia della Basilicata for their support. Finally, we are very grateful to the anonymous reviewers of AASC for their useful comments and feedback on an earlier draft of this paper.

Open Access This article is distributed under the terms of the Creative Commons Attribution 4.0 International License (http:// creativecommons.org/licenses/by/4.0/), which permits unrestricted use, distribution, and reproduction in any medium, provided you give appropriate credit to the original author(s) and the source, provide a link to the Creative Commons license, and indicate if changes were made.

\section{References}

Attema PAJ, Burgers G-J, van Leusen PM (2010) Regional pathways to complexity: settlement and land-use dynamics in early Italy from the bronze age to the republican period. Amsterdam University Press, Amsterdam

Attwell M, Fletcher M (1985) A new technique for investigating spatial relationships: significance testing. In: Voorrips A, Loving SH (eds) To pattern the past: symposium on mathematical methods in archaeology, Amsterdam 1984. Conseil de l'Europe, Strasbourg, pp 181189

Attwell MR, Fletcher M (1987) An analytical technique for investigating spatial relationships. J Archaeol Sci 14(1):1-11. https://doi.org/10. 1016/S0305-4403(87)80002-X

Azzena G, Tascio M (1996) Il Sistema Informativo Territoriale per la carta archeologica d'Italia. In: Marchi ML, Sabbatini G, Venusia (IGM 187 I NO / I NE) (Forma Italiae 37). Leo S. Olschki, Firenze, pp 281-297

Barker G, Lloyd J (eds) (1991) Roman landscapes: archaeological survey in the Mediterranean region. British School at Rome, London

Barker G, Mattingly DJ (1999) The archaeology of Mediterranean landscapes. Oxbow Books, Oxford

Bintliff JL, Sbonias K (eds) (1999) Reconstructing past population trends in Mediterranean Europe (3000 BC-AD 1800). Oxbow Books, Oxford

Bintliff JL, Sbonias K (2000) Demographic and ceramic analysis in regional survey. In: Francovich R, Patterson H, Barker G (eds) Extracting meaning from ploughsoil assemblages. Oxbow Books, Oxford, pp 244-258

Bispham E (2006) Coloniam deducere: how Roman was Roman colonization during the Middle Republic? In: Bradley G, Wilson JP (eds) Greek and roman colonization: origins, ideologies and interactions. Classical Press of Wales, Swansea, pp 73-160

Bottini A (1980) L'area melfese dall'età arcaica alla romanizzazione (VIIII sec. a.C.). In: Attività archeologica in Basilicata 1964-1977. Studi in onore di Dinu Adamesteanu, Matera, pp 313-344

Bottini A (1982) Il melfese fra VII e V secolo a.C.. Dialoghi di. Archeologia 4(2):152-160

Bottini A (2001) Ripacandida. BTCGI, XVI, pp 180-182

Bottini A (2016) Popoli anellenici in Basilicata, mezzo secolo dopo. In: Marchi ML (ed) Identità e conflitti tra Daunia e Lucania Preromane. Edizioni ETS, Pisa, pp 7-50
Bradley G (2006) Colonization and identity in republican Italy. In: Bradley G, Wilson JP (eds) Greek and Roman colonization: origins, ideologies and interactions. Classical Press of Wales, Swansea, pp 161-187

Brown FE (1980) Cosa: the making of a Roman town. University of Michigan Press, Ann Arbor

Buck RJ (1971) The Via Herculia. Papers of the British School at Rome 39:66-87

Buck RJ (1981) The ancient roads of northwestern Lucania and the battle of Numistro. La Parola del Passato 36:317-347

Capogrossi Colognesi L (2002) Persistenza e innovazione nelle strutture territoriali dell'Italia Romana. L'ambiguità di una interpretazione stroriografica e dei suoi modelli. Jovene, Napoli

Carandini A (1994) I paesaggi agrari dell'Italia romana visti a partire dell'Etruria. In: L'Italie d'Auguste à Dioclétien, Actes du colloque international de Rome (25-28 mars 1992) 198 (1). École Française de Rome, Rome, pp 167-174

Carandini A, Cambi F, Celuzza MG, Fentress E (2002) Paesaggi d' Etruria. Valle dell' Albegna, Valle d'Oro, Valle del Chiarone, Valle del Tafone. Edizioni di Storia e Letteratura, Roma

Casarotto A (2017) Location preferences of rural settlements in the territory of Venusia: an inductive approach. In: Kamermans H, Bakels CC (ed) Excerpta Archaeologica Leidensia II. Analecta Praehistorica Leidensia 47:163-209

Casarotto A, Pelgrom J, Stek TD (2016) Testing settlement models in the early Roman colonial landscapes of Venusia (291 BC), Cosa (273 BC) and Aesernia (263 BC). J Field Archaeol 41(5):568-586. https://doi.org/10.1080/00934690.2016.1211474

Casarotto A, Stek TD, Pelgrom J, van Otterloo RH, Sevink J (2017) Assessing visibility and geomorphological biases in regional field surveys: the case of Roman Aesernia. Geoarchaeol Int J 00:1-16. https://doi.org/10.1002/gea.21627

Celuzza MG, Regoli E (1982) La Valle d'Oro nel territorio di Cosa. Ager Cosanus e Ager Veientanus a confronto. Dialoghi di Archeologia 4: $31-62$

Conolly J, Lake M (2006) Geographical information systems in archaeology. Cambridge University Press, Cambridge

Crawford MH (1995) La storia della colonizzazione romana secondo i Romani. In: Storchi Marino A (ed) L'incidenza dell'antico. Studi in memoria di Ettore Lepore. I. Luciano Editore, Napoli, pp 187-192

De Cazanove O (2005) Les colonies latines et les frontières régionales de 1'Italie. Venusia et Horace entre Apulie et Lucanie: Satires, II, 1, 34. Mélanges de la Casa de Velázquez 35(2):107-124

De Guio A (1985) Archaeological applications of survival analysis. In: Voorrips A, Loving SH (eds) To pattern the past: symposium on mathematical methods in archaeology, Amsterdam 1984. Conseil de l'Europe, Strasbourg, pp 361-381

De Guio A (1988-1989) Analisi funzionale dei 'paesaggi di potere'. Origini XIV, pp 447-478

De Guio A, Secco G (1988) Archaeological applications of the 'Percolation Method' for data analysis and pattern recognition. In: Rahtz SPQ (ed) Computer and quantitative methods in archaeology 1988, CAA88 (BAR international series 446 (i)). BAR, Oxford, pp 63-93

De Guio A, Evans SP, Ruta Serafini A (1986) Marginalità territoriale ed evoluzione del "paesaggio di potere": un caso di studio nel Veneto. Quaderni di Archeologia del Veneto II: 160-172

Dores Cruz M (2011) "Pots are pots, not people:" material culture and ethnic identity in the Banda Area (Ghana), nineteenth and twentieth centuries. Azania Archaeol Res Africa 46(3):336-357. https://doi. org/10.1080/0067270X.2011.629525

Ducke B, Kroefges PC (2008) From points to areas: constructing territories from archaeological site patterns using an enhanced Xtent model. In: Posluschny A, Lambers K, Herzog I (ed) Layers of perception. Proceedings of the 35th International Conference on Computer Applications and Quantitative Methods in Archaeology 
(CAA), Berlin, Germany, April 2-6, 2007 (Kolloquien zur Vor- und Frühgeschichte, Vol. 10). Bonn, pp 245-251

Eastman JR (2012) IDRISI Selva Manual (Manual Version 17.01). Clark Labs, Clark University, Worcester

Eastman JR (2016) TerrSet manual. Clark Labs, Clark University, Worcester

Esri (2014) How aspect works. In: ArcGIS 10.2.2 Help

FAO (2006) Guidelines for soil description, 4th edn. Food and Agriculture Organization of the United Nations, Rome

FAO (2014) World reference base for soil resources 2014, International soil classification system for naming soils and creating legends for soil maps (update 2015). Food and Agriculture Organization of the United Nations, Rome

Fentress E (2000) What are we counting for? In: Francovich R, Patterson $\mathrm{H}$, Barker $\mathrm{G}$ (ed), Extracting meaning from ploughsoil assemblages, Oxbow Books Oxford: 45-52

Fracchia H (2013) Survey, settlement and land use in Republican Italy. In: DeRose Evans J (ed) A Companion to the Archaeology of the Roman Republic. Blackwell Publishing Ltd., pp 181-197

Francovich R, Patterson H, Barker G (eds) (2000) Extracting meaning from Ploughsoil assemblages. Oxbow Books, Oxford

Frayn JM (1979) Subsistence farming in Roman Italy. Centaur Press Ltd, Fontwell

Gabba E (1977) Considerazioni sulla decadenza della piccola proprietà contadina nell'Italia centro-meridionale del II secolo a.C. Ktema II: 269-284

Goodchild H (2007) Modelling Roman agricultural production in the Middle Tiber Valley, Central Italy. Ph.D. dissertation, University of Birmingham, eTheses Repository. http://etheses.bham.ac.uk/175/

Goodchild H (2013) GIS models of Roman agricultural production. In: Bowman A, Wilson A (eds) The Roman agricultural economy: organization, investment, and production. Oxford University Press, Oxford, pp 55-83

Gualtieri M (2002) Insediamenti e proprietà nella Lucania nord-orientale (I sec. a.C. - III sec. d.C.) In: Lo Cascio E, Storchi Marino A (eds) Modalità insediative e strutture agrarie nell'Italia Meridionale in età Romana. Edipuglia, Bari, pp 75-102

Isayev E (2007) Inside ancient Lucania. Dialogues in history and archaeology. Institute of Classical Studies, London

Kamermans H (2000) Land evaluation as predictive modelling: a deductive approach. In: Lock G (ed) Beyond the map: archaeology and spatial technologies. IOS Press, Amsterdam, pp 124-146

Kamermans H, Wansleeben M (1999) Predictive modelling in Dutch archaeology, joining forces. In: Barceló JA, Briz I, Vila A (ed) New techniques for old times. CAA98. Computer Applications and Quantitative Methods in Archaeology. Proceedings of the 26th Conference, Barcelona, March 1998 (BAR International Series 757). Archaeopress, Oxford, pp 225-230

Kvamme KL (1990) One-sample tests in regional archaeological analysis: new possibilities through computer technology. Am Antiq 55(2):367-381. https://doi.org/10.2307/281655

Launaro A (2011) Peasants and slaves. The rural population of Roman Italy (200 BC to AD 100). Cambridge University Press, Cambridge

Marchi ML (1991) Venosa: ceramica di tradizione non romana. In: Salvatore M (ed) Il Museo Archeologico Nazionale di Venosa. IEM editrice, Matera, pp 86-91

Marchi ML (2000) Effetti del processo di romanizzazione nelle aree interne centro-meridionali. Acquisizioni, innovazioni ed echi tradizionali documentati archeologicamente. Orizzonti I:227-242

Marchi ML (2004) Fondi, Latifondi e proprietà Imperiali nell'Ager Venusinus. Agri centuriati 1:129-156

Marchi ML (2009) Modi e forme dell'urbanizzazione della Daunia. In: Osanna M (ed) Verso la città. Forme insediative in Lucania e nel mondo italico fra IV e III sec. a.C. Osanna Ed., Venosa, pp 327-367
Marchi ML (2010) Ager Venusinus II (IGM 175 II SO; 187 I NO; 187 I SE; 188 IV NO; 188 IV SO) (Forma Italiae 43). Leo S. Olschki, Firenze

Marchi ML (2014) The landscape of Daunia: Ager Venusinus. In: Small AM (ed) Beyond Vagnari, new themes in the study of Roman South Italy. Edipuglia, Bari, pp 181-192

Marchi ML (2016) Sanniti in Daunia. Dinamiche insediative tra VI e III secolo a.C. In: Marchi ML (ed) Identità e conflitti tra Daunia e Lucania Preromane. Edizioni ETS, Pisa, pp 51-84

Marchi ML, Sabbatini G (1996) Venusia (IGM 187 I NO / I NE) (Forma Italiae 37). Leo S. Olschki, Firenze

Marchi ML, Salvatore M (1997) Venosa: forma e urbanistica (Città antiche in Italia 5). «L'Erma» di Bretschneider, Roma

Musti D (2009) Lucanus an Apulus anceps. Il territorio dei Lucani e i suoi confini fra il IV e il I sec. a.C. In: Osanna M (ed) Verso la città. Forme insediative in Lucania e nel mondo italico fra IV e III sec. a.C. Osanna Ed., Venosa, pp 13-24

Nuninger L, Verhagen P, Bertoncello F, Castrorao Barba A (2016) Estimating "Land Use Heritage" to model changes in archaeological settlement patterns. LAC 2014 Proceedings, 0, 12. https://doi.org/ 10.5463/lac.2014.60

Odum EP (1959) Fundamentals of ecology. W. B. Saunders Company, Philadelphia

Osanna M (2010) Paesaggi agrari e organizzazione del territorio in Lucania tra IV e III sec. a.C. Bollettino di Archeologia on line, Volume Speciale, pp 17-31

Patterson J (2006) Colonization and historiography: the Roman Republic. In: Bradley G, Wilson JP (eds) Greek and roman colonization: origins, ideologies and interactions. Classical Press of Wales, Swansea, pp 189-219

Pelgrom J, Stek TD (2014) Roman colonization under the republic: historiographical contextualisation of a paradigm. In: Stek TD, Pelgrom J (eds) Roman republican colonization. New perspectives from archaeology and ancient history. Palombi Editori, Rome, pp $10-45$

Pelgrom J, Tetteroo C (2015) Preliminary results from the Ager Venusinus project. Fieldreport of the 2013 and 2014 campaigns. Internal report for the Soprintendenza Archeologica della Basilicata

Pelgrom J, Marchi ML, Cantoro G, Casarotto A, Hamel A, Lecce L, García Sánchez J, Stek TD (2014) New approaches to the study of village sites in the territory of Venosa in the Classical and Hellenistic periods. Agri centuriati 11:31-60. https://doi.org/10.1400/233577

Pelgrom J, Lecce L, García Sánchez J, Stek TD (2016) Le indagini olandesi sul pianoro di Masseria Casalini Sottana (2013-2014). In De Siena A, Giammatteo T (eds) Palazzo San Gervasio. Modalità insediative e pratiche funerarie dal territorio. Osanna Edizioni, Venosa, pp 277-288

Rathbone DW (1981) The development of agriculture in the "Ager Cosanus' during the Roman Republic: problems of evidence and interpretation. J Roman Stud 71:10-23. https://doi.org/10.2307/ 299493

Rathbone DW (2008) Poor peasants and silent sherds. In: De Ligt L, Northwood SJ (eds) People, land and politics, demographic developments and the transformation of Roman Italy, 300 BC-AD, vol 14. Brill, Leiden, pp 305-332

Renfrew C, Level EV (1979) Exploring dominance: predicting polities from centers. In: Renfrew C, Cooke KL (eds) Transformations: mathematical approaches to culture change. Academic Press, New York, pp 145-167

Roppa A, Van Dommelen P (2012) Rural settlement and land-use in Punic and Roman Republican Sardinia. J Roman Archaeol 25:49 68

Sabbatini G (2001) Ager Venusinus I. Mezzana del Cantore (IGM 175 II SE) (Forma Italiae 40). Leo S. Olschki, Firenze

Salmon ET (1967) Samnium and the Samnites. Cambridge University Press, Cambridge 
Salmon ET (1969) Roman colonization under the Republic. Thames and Hudson, London

Salvatore M (ed) (1984) Venosa: un parco archeologico ed un museo. Come e perchè. Editrice Scorpione, Taranto

Settis S (ed) (1984) Misurare la terra: centuriazione e coloni nel mondo romano. Edizioni Panini, Modena

Sewell J (2016) Higher-order settlements in early Hellenistic Italy: a quantitative analysis of a new archaeological database. Am J Archaeol 120(4):603-630. https://doi.org/10.3764/aja.120.4.0603

Shennan S (1988) Quantifying archaeology. Edinburgh University Press, Edinburgh

Shennan SJ (ed) (1994) Archaeological approaches to cultural identity. Routledge, London

Siegel S (1956) Nonparametric statistics for the behavioral sciences. McGraw-Hill, New York

Spurr MS (1986) Arable cultivation in Roman Italy c. 200 B.C. - c. A.D. 100 (Journal of Roman Studies Monographs, 3). Society for the Promotion of Roman Studies, London

Stek TD (2012) Review of: Marchi M. L. (2010) Ager Venusinus II. Forma Italiae 43. BABesch 87:243-244

Stek TD (2013) Material culture, italic identities and the romanization of Italy. In: DeRose Evans J (ed) A Companion to the archaeology of the Roman Republic. Blackwell Publishing Ltd., pp 337-353

Stek TD, Pelgrom J (2013) Landscapes of early Roman colonization: Non-urban settlement organization and Roman expansion in the Roman Republic (4th-1st centuries B.C.) Tijdschrift voor Mediterrane Archeologie 50:87

Stek TD, Modrall EB, Kalkers RAA, van Otterloo RH, Sevink J (2015) An early Roman colonial landscape in the Apennine mountains: landscape archaeological research in the territory of Aesernia (Central-Southern Italy). Analysis Archaeologica: An International Journal of Western Mediterranean Archaeology 1:229-291

Tagliamonte G (1996) I Sanniti: Caudini, Irpini, Pentri, Carricini, Frentani. Longanesi, Milano

Tarquini S, Nannipieri L (2017) The 10 m-resolution TINITALY DEM as a trans-disciplinary basis for the analysis of the Italian territory: current trends and new perspectives. Geomorphology 281:108115. https://doi.org/10.1016/j.geomorph.2016.12.022

Tarquini S, Isola I, Favalli M, Mazzarini F, Bisson M, Pareschi MT, Boschi E (2007) TINITALY/01: a new triangular irregular network of Italy. Ann Geophys 50(3):407-425. https://doi.org/10.4401/ag4424

Tarquini S, Vinci S, Favalli M, Doumaz F, Fornaciai A, Nannipieri L (2012) Release of a 10-m-resolution DEM for the Italian territory: comparison with global-coverage DEMs and anaglyph-mode exploration via the web. Comput Geosci 38(1):168-170. https://doi.org/ 10.1016/j.cageo.2011.04.018

Terrenato N (2001) Introduction. In: Keay S, Terrenato N (eds) Italy and the west. Comparative issues in Romanization. Oxbow Books, Oxford, pp 1-6

Terrenato N (2007) The essential countryside: the roman world. In: Alcock SE, Osborne R (eds) Classical archaeology. Blackwell, Malden, pp 139-161
Terrenato N (2012) The enigma of "Catonian" villas: the De agri cultura in the context of second-century BC Italian architecture. In: Becker JA, Terrenato N (eds) Roman Republican villas: architecture, context and ideology. The University of Michigan Press, Ann Arbor, pp 69-93

Torelli M (1990) La formazione della villa. In: Clemente G, Coarelli F, Gabba E (ed) Storia di Roma. 2. L'impero mediterraneo. I. La Repubblica Imperiale. Einaudi, Torino, pp 123-132

Torelli M (1991) La fondazione di Venosa nel quadro della romanizzazione dell'Italia meridionale. In: Salvatore M (ed) Il Museo archeologico nazionale di Venosa. IEM editrice, Matera, pp $17-26$

Torelli M (1992) Venosa romana. In: Fedeli P (ed) Venosa, Venosa, pp 35-77

Torelli M (1999) Tota Italia: essays in the cultural formation of Roman Italy. Clarendon Press, Oxford

Van Dommelen P, Terrenato N (2007) Local cultures and the expanding Roman Republic. In: Van Dommelen P, Terrenato N (ed) Articulating local cultures, power and identity under the expanding Roman Republic. Journal of Roman archaeology, JRA supplementary series number 63, Portsmouth, pp 7-12

Van Joolen E (2003) Archaeological land evaluation. A reconstruction of the suitability of ancient landscapes for various land uses in Italy focused on the first millennium BC. PhD dissertation. University of Groningen, University of Groningen Research Database. http://hdl. handle.net/11370/78b6a5bf-917d-4a15-969d-230c3c72b690

Van Leusen PM (2002) Pattern to process: methodological investigations into the formation and interpretation of spatial patterns in archaeological landscapes. Ph.D. dissertation. University of Groningen, University of Groningen Research Database. http://hdl.handle.net/ 11370/fc9ead23-e2c7-40c5-942f-e06f52198222

Van Leusen PM, Kamermans H (eds) (2005) Predictive modelling for archaeological heritage management: a research agenda, Nederlandse Archeologische Rapporten, vol. 29. Rijksdienst voor het Oudheidkundig Bodemonderzoek, Amersfoort

Vermeulen F (2017) From the mountains to the sea. The Roman colonisation and urbanisation of Central Adriatic Italy. Babesch Supplements 30, Peeters, Leuven

Vink APA (1975) Land use in advancing agriculture. Springer - Verlag, Berlin

Vinson P (1979) Il percorso della Via Appia tra Venosa e Palazzo S. Gervasio. Lucania Archeologica 3:15-18

Vita-Finzi C, Higgs ES (1970) Prehistoric economy in the Mount Carmel area of Palestine: site catchment analysis. Proc Prehist Soc 36:1-37

Volpe G (1990) La Daunia nell'età della romanizzazione: paesaggio agrario, produzione, scambi. Edipuglia, Bari

Wheatley D, Gillings M (2002) Spatial technology and archaeology. The archaeological applications of GIS. Taylor and Francis, London

White KD (1970) Roman farming. Thames and Hudson, London

Witcher R (2008) (Re)surveying Mediterranean rural landscapes: GIS and legacy survey data. Internet Archaeol (24). 10.11141/ia.24.2

Wood J (2009) The LandSerf Manual. http://www.staff.city.ac.uk/ jwo/ landserf/landserf230/doc/landserfManual.pdf 